\title{
A construção da memória historiográfica paulista \\ Dom Luiz de Céspedes Xeria e o mapa de sua expedição de 1628
}

\begin{abstract}
Airton José Cavenaghi ${ }^{1}$
RESUMO: Neste estudo, referencia-se a análise do mapa de Dom Luiz de Céspedes Xeria que representa o território paulista em 1628. Apresenta-se, também, a imagem original do mapa, que se encontra sob a guarda do Archivo General de Indias, localizado na cidade de Sevilha, na Espanha. Essa mapa original é comparado à sua tradicional reprodução, presente na obra Collectanea de mappas de cartographia paulista antiga de Afonso de Taunay, de 1922. Na análise comparativa realizada pela confrontação dessas fontes primárias, busca-se demonstrar como uma documentação primária pode adquirir características que a identifiquem com necessidades mais amplas e significativas, associadas à gestão e administração de uma memória coletiva, estruturada para a manutenção de poderes e valores de uma determinada classe social hegemônica. Tal fato não é percebido, ou considerado, como algo planejado ou arquitetado de forma maquiavélica e significativa, e, sim, como parte de significações inconscientes e necessárias à manutenção da identidade cultural desse mesmo grupo social hegemônico.

PALAVRAS-ChAVE: História. Cartografia. Memória. São Paulo. Século XVI.

ABSTRACT: This study presents an analysis of the map of Don Luis de Cespedes Xeria, which represents the state of São Paulo in 1628, based on the image of the original map that is under custody of the Archivo General de Indias, located in Seville, Spain. This map is compared with the traditional map reproduced by Afonso de Taunay, in 1922, in the Collectanea de mappas de cartographia paulista antiga. By comparison of these primary sources, it is shown that a source can acquire characteristics related to the broader and significant needs associated with the management and administration of a collective memory, which is structured to maintain the power and values of a particular social, hegemonic class. This fact is not noticed as something of a Machiavellian nature and significantly planned or architected, but as part of an unconscious pattern, necessary to maintain the cultural identity of that hegemonic social group.

KEYWORDS: History. Cartography. Memory. São Paulo. Sixteenth century.
\end{abstract}

1. Doutor em História Social pela Faculdade de Filosofia, Letras e Ciências Humanas da Universidade de São Paulo, professor e pesquisador do Mestrado em Hospitalidade, Universidade Anhembi Morumbi (UAM-SP). E-mail: <acavenaghi@gmail.com>; $<$ cavenagh@usp.br>.Este artigo, agora ampliado com novas discussões e análises, foi inicialmente apresentado no 3. Simpósio de Iberoamericano de História da Cartografia (FFLCH-USP), São Paulo, abril de 2010. Para detalhes ver: $<$ http://3siahc.wordpress. com/memorias/>. 
2. Cf. Carlos Alberto Vesentini (1997, p. 65).

3. Cf. Jörn Rüsen (2001, p. 66).
Introdução

A produção de uma memória histórica caminha por várias e múltiplas vertentes. Segundo Vesentini, "para a memória do fato apresentar-se [...] seria necessário pensar uma ampla difusão dele, capaz de alcançar a todos" 2 . Seu rastreamento só é possível quando se observa a totalidade dos elementos envolvidos em seu resgate e reconstrução. Assim, quando o sentido de um objeto e de sua historicidade é apresentado, ele passa a ser, em si, a materialização - o elemento tangível - de um amplo e complexo modelo de identidade sociocultural de um grupo específico. Dessa forma, sua passagem e transformação em elemento de verdade absoluta ocorre quando a memória é moldada e referenciada, seja em sua aplicação diária, ou em seu resgate ilustrativo e oportuno na prática da interpretação histórica, ou seja: "A narrativa histórica é um meio de constituição da identidade humana"3.

Neste artigo se analisa a transformação de um objeto iconográfico no caso, o mapa realizado durante a expedição de Dom Luiz Céspedes Xeria ao Paraguai no ano de 1628, e, posteriormente, reproduzido em obra organizada por Affonso de E. Taunay publicada em 1922 - em um objeto de referência e verdade absoluta. Procura-se demonstrar como a memória desse mesmo objeto, usada de maneira equivocada por Taunay, propagou-se e se afirmou como um documental histórico imprescindível para a compreensão da história formativa do território paulista.

Origina-se, nesse objeto cartográfico, todo um mito interpretativo referente à formação da memória paulista. Ao resgatar o mapa original - aquele produzido no ano de 1628 -, busca-se analisar o processo de criação desse mito, além de analisar os motivos que, após 1922, levaram à sua propagação e divulgação ao público em geral.

No processo de divulgação do mapa - após ser estruturalmente modificado -, Taunay transformou-o em um referencial da história paulista, pois nele se encontraria, pela primeira vez, a representação direta, pela observação local do visitante, de elementos arquitetônicos da então Vila de São Paulo. E, também pela primeira vez, era apresentada ao público uma suposta imagem da Vila nos momentos iniciais de sua formação, mesmo que a representação focalizasse apenas um pequeno edifício, que Taunay identificou como sendo o da Casa da Câmara.

No ano de 1628, com mais de oitenta anos de fundação, a então vila de São Paulo ainda era considerada um local de difícil acesso. Distante cerca de 9 léguas do litoral (aproximadamente 54 quilômetros) no sentido serra acima, a cidade vivia certo isolamento em relação ao restante da ocupação portuguesa no litoral paulista. A esse respeito, Janice Theodoro da Silva argumenta que "A vila de São Paulo ocupava um lugar periférico na economia colonial do século XVII [...] As dificuldades de contato - sobretudo a travessia da 
Serra do Mar - impediam, entretanto, uma circulação constante entre o Planalto e Santos"4.

$\bigcirc$ isolamento referido encontrava-se vinculado apenas à questão da ligação administrativa com a Coroa, que se realizava via São Vicente. Para o resto do território ainda não colonizado pelos europeus, a Vila de São Paulo passaria a ser importante ponto de partida para a exploração do interior do país.

As condições geográficas da localidade favoreciam tal procedimento e, ao analisar relatos de viajantes deste período, é o próprio Taunay que argumenta: "Desde os dias da descoberta, por assim dizer mostrara Uhrico Sclmiidel a facilidade relativa da viagem do Paraguay a S. Paulo. Em princípios do século $\mathrm{XVIl}$ foram numerosos os portuguezes e paulistas que pelo interior das terras vicentinas procuraram galgar o Paraguay ${ }^{\prime \prime}$.

Escrito na mesma época da publicação da Colletânea de mapas, outro livro de Taunay, Na era das Bandeiras, serve como elemento direcionador de seu pensamento à frente da diretoria do Museu Paulista. Nesse período, o que se procurava era a comprovação direta de um modelo político que assegurava, a São Paulo e a seu território, já naquele período, a supremacia da união nacional ${ }^{6}$.

No século XVII, o território paulista ainda era uma incógnita para o europeu. A escolha pela ocupação do litoral criou circunstâncias propícias ao desenvolvimento de uma economia baseada na exploração de produtos econômicos de grande rentabilidade imediata. Nesse sentido, a captura dos índios para o trabalho em monoculturas açucareiras na região da Capitania de Pernambuco, transformou o território paulista - e, como centro irradiador, a cidade de São Paulo - em um local propício ao fornecimento desse tipo de mão de obra. Os paulistas ficariam conhecidos como renegados do sertão, assassinos de índios, distantes das ações organizacionais propostas pela Coroa portuguesa - no período, conhecido como o da União Ibérica, sob supremacia de Felipe IV, rei de Espanha.

cotidiano do território era vinculado bem mais aos aspectos culturais dos antigos habitantes da terra do que às ações administrativas propostas pelos europeus. A presença da Companhia de Jesus, desde a fundação da cidade de São Paulo em 1554, indicava que, para vencerem-se as circunstâncias e a resistência indígena, a dominação deveria ser realizada pela incorporação dos costumes locais, que seriam paulatinamente substituídos pelas necessidades culturais impostas pelos europeus.

Essa ação de conquista é relatada por Gloria Kok:

Do intenso convívio dos habitantes da Capitania de São Paulo com as populações indígenas, seja por apressar os "negros da terra" como escravos, seja através das relações de parentesco firmadas durante a conquista, derivou uma progressiva decodificação dos territórios indígenas, incentivado pelas autoridades portuguesas com o intuito de garantir o domínio dos habitantes e de suas terras? ${ }^{7}$.
4. Cf. Janice Theodoro da Silva $(1984$, p. 54)

5. Cf. Affonso de E. Taunay (1922b, p. 88)

6. Relacionado ao assunto, ver: Ana Claudia F. Brefe, (2005); e Cecília Helena de Salles Oliveira e Claudia Valladão de Mattos (1999).

7.Cf. Gloria Kok (2009,p.92). 
8. Para compreender melhor como esta caracterização evolui, ver Maria Vicentina de P. do A. Dick (1997).

9. Cf. Bronislaw Malinowski (1975, p. 35).

10. Aziz Ab'Saber, apud Eduardo Bueno (2004, p. 35).

11. Cf. Denis Wood (1992, p. 143).

12. Cf. Sérgio B. de Holanda (1994, p. 19).
Essa decodificação apontada por Kok ainda hoje se revela pertinente, pois, nesse território, em especial na cidade de São Paulo, os vestígios da ocupação indígena original ainda são observados, por exemplo, na toponímia existente. Várias regiões da cidade ainda preservam seus nomes ligados à linguagem e aos costumes indígenas, tais como Anhangabaú, Tamanduateí, entre outros, embora a população atual provavelmente não mantenha com essas nomeações uma identificação cultural formativa ${ }^{8}$. Tais locais e suas denominações podem ser considerados como espécies de "fósseis culturais" - análise baseada na antiga vertente analítica da escola evolucionista da antropologia; ou mesmo em uma noção mais contemporânea de "sobrevivência" ou, inclusive, "permanência" - para os quais, mesmo não perdendo a essência de sua origem formativa, os locais e suas referências de identificação produzem novas realidades, reestruturadas em novos valores e significados cotidianos?.

A esse respeito, Aziz Ab'Saber comenta: "Disso tudo resulta que a gente tem de respeitar a toponímia dos que sabiam observar relevo, vegetação e todos os fenômenos da natureza" 10 .

Os mapas e plantas cartográficas sertanistas: significações gerais

Confeccionar uma representação do espaço vivenciado é um mecanismo de criação a partir de uma realidade necessária ao momento cotidiano vivido. A cartografia entre os séculos XVI e XVII, em terras paulistas, em algumas ocasiões tem sido associada - como apontam as análises de Taunay (1922) e de Sérgio Buarque de Holanda (1994) - à ausência, em seus produtores, de conhecimentos técnicos específicos. Denis Wood, em interessante trabalho lançado em 1992, relembra que "cada signo possui uma história" ${ }^{11}$. A simbologia sertanista de representação acompanha tal realidade de pensamento e constitui um modelo pouco analisado (ou mesmo pouco percebido) ao resgatarem-se os conceitos formativos do espaço geográfico brasileiro.

A primeira noção importante da percepção deste estilo cartográfico é a praticamente ausência de representações de limites ou de fronteiras. Os mapas representam noções simbólicas daqueles que percebem o espaço a ser mapeado pela sua presença in loco. O que é visto é aquilo a ser posto no mapa, e é esta caracterização que transforma as representações em "toscos desenhos [com] nomes estropiados"12, como definidas inicialmente por Sérgio Buarque de Holanda em sua magnífica análise da materialidade da história paulista durante o século XVII.

O homem contemporâneo não observa que, naquilo que está sendo desenhado, não se encontra uma expressão clássica de cientificidade: o que é representado denota uma percepção material do que é sentido e observado, mesmo o padrão de representação não oferecendo um método de reprodução sistemática do conhecimento.

Mário Clemente Ferreira, reproduzindo informações de Jaime Cortesão, argumenta que: 
Nesses primeiros tempos as informações e as representações daqueles sertões disponíveis em São Paulo e no Rio de Janeiro eram fornecidas por sertanistas, mineiros e bandeirantes que se tinham embrenhado por aquelas terras. A par de inúmeros relatos de viagens, foram traçados mapas que na verdade não passavam de simples esboços cartográficos onde eram representados os mais recentes conhecimentos empíricos adquiridos por esses homens, desenhados aliás de forma grosseira e muito esquemática ${ }^{13}$.

Jaime Cortesão, ainda em 1971, apesar de seu notório saber e conhecimento histórico, não observava a cartografia como muito mais do que um "manancial documental". Fato que a simplifica e não a identifica como um dos elementos fundamentais das representações culturais de um povo. A necessária padronização dos elementos pictóricos na observação dos desenhos realizados é um saber acadêmico e conforme à cientificidade existente, passível de reprodução e permanência. Tal modo de reproduzir favorece a manutenção de uma esfera de poder dominante, sendo necessário tanto à sistematização de um espaço quanto à legitimação daqueles que o inserem em um círculo cultural hegemônico.

A caracterização seiscentista, os ditos "desenhos rudimentares" ou "toscos", permaneceu na representação do território paulista, por exemplo, até meados das décadas iniciais do século XIX, ou seja, em um espaço de conhecimento indígena e, no caso do imaginário da cartografia sertanista, é isso que pode ser observado ${ }^{14}$.

A herança indígena, já discutida por Kok ${ }^{15}$, é resultado de uma transição cultural específica da região paulista. Deve-se notar que, na visão do colonizador europeu, muito do território permaneceu "desconhecido", mesmo após seu primeiro mapeamento oficial em 1837, por Daniel Pedro Muller. Nesse período, o interior do atual estado de São Paulo, entre a cidade de Araraquara e as da região Noroeste, ainda permanecia praticamente ocupado por grupos indígenas que, na época, eram denominados "índios ferozes"; e os terrenos associados à sua presença, "desconhecidos".

A percepção do espaço e sua representação envolvem a necessidade de sistematização e uso. Os elementos tangíveis - que, neste caso específico, manifestam-se na representação de uma memória cartográfica - representam, assim, tal sistematização.

Como já argumentado, o mapeamento do território paulista só vai estruturar uma necessidade administrativa mais acentuada após o início do século XIX e, mesmo neste momento de transição, a herança sertanista na visualização do espaço percorrido ainda se manifestaria de forma presente. Os "toscos" desenhos alardeados por Sérgio Buarque de Holanda ganhariam nova roupagem, embora ainda permanecessem vinculados às caracterizações iconográficas referentes ao passado colonial do território.

Assim, a representação do espaço vivenciado desenvolve-se pela ação de mecanismos culturais implícitos ao grupo social ao qual um suposto cartógrafo pertence. "A habilidade cartográfica pressupõe por parte do cartógrafo primitivo o talento de abstrair e simbolizar, assim também um talento comparável da pessoa
13. Ver Mario Clemente Ferreira (2007).

14. Ver: Airton J. Cavenaghi (2006).

15. Ver Gloria Kok, (2009) 
16. Ver Yi-Fu Tuan (1983, p 87). que observa, pois esta deve conhecer como traduzir pontos e linhas contorcidas em realidades do terreno." ${ }^{16}$.

A compreensão, daqueles que confeccionam o mapa sertanista, dessa realidade imediata de representação é, nada mais nada menos, do que a absorção do cotidiano vivenciado por eles. Nesse aspecto, tais desenhos "toscos" são, de fato, expressões de significados reais, que se metamorfoseiam em símbolos coerentes e pertinentes à temática existente no período.

mapa de Céspedes Xeria e o território paulista: caracterização do conteúdo reproduzido

Na compreensão e percepção da formação do imaginário paulista e de sua cartografia de referência, assume grande importância a divulgação do primeiro mapa do sertão paulista produzido após a presença europeia na região.

Em 1628, o então governador do Paraguai Dom Luiz de Céspedes Xeria, de passagem pela cidade de São Paulo a caminho do Paraguai, produziria uma representação do território que se tornaria, pela presença de alguns desenhos de edificações, o elemento mítico formativo da identidade visual paulistana

De fato, o mapa de Céspedes Xeria é fruto da época inicial do ciclo das Entradas e Bandeiras. Os homens do período não eram formados em academias nem detentores, ao menos, dos conhecimentos clássicos dos bancos escolares. Representavam conforme observavam, e é nesse contexto que suas produções culturais devem ser compreendidas.

A primeira indicação da existência do mapa de Xeria é encontrada na obra compilada, em 1912, pelo Reverendo Padre Pablo Pastells, reunindo, em quatro grandes volumes, o material encontrado em arquivos espanhóis referentes à presença da Companhia de Jesus no território do atual Paraguai. No primeiro tomo da obra organizada, é possível identificar a seguinte referência:

439.

$162874-4-15$

Mapa presentado á S. M. por D. Luis de Céspedes Xeria para la mejor inteligencia del viaje que hizo desde la 'Villa de San Pablo del Brasil á la Ciudad Real del Guayrá.- Delínea el río Ayembí, por donde bajó hasta la confluencia del Río de la Plata, por el cual prosiguió su viaje. Describe las corrientes más rápidas y los puertos que halló, los altos peligrosos é islas encontradas, la abundancia de pescado y la grandísima suma de caza de tigres, leones, y muchísimas antas de que se sustentaban; pone, por ñn, lista é interpretación de 24 ríos que figuran em dicho mapa. Duplicado.-1, $18 \times 0,79 \mathrm{~m}^{17}$.

Nessa prancha cartográfica, transcrita na obra do jesuíta Pastells, é encontrada diretamente a origem dessa percepção da realidade cartográfica difundida naquele momento de sua reprodução e publicação original: uma descrição pormenorizada do território no qual, neste caso, a viagem realizou-se. 
Ao observamos, na atualidade, a reprodução encomendada por Taunay para o mapa de Xeria, há, para nós, uma permanência de valores constituídos, pois a apropriação de seu conteúdo ideológico é feita de forma quase natural. Não ocorre um questionamento direto dessa ação nem tampouco a análise dos significados existentes em sua representação, divulgados já desde a época de sua reprodução inicial, em 1922.

Questiona-se, assim, a veracidade do documental primário e, também, como sua divulgação - por pessoas ligadas à formação da mentalidade paulista - foi considerada única, sem a necessária revisão, fosse crítica ou metodológica.

Esse questionamento se inicia com a apresentação do objeto central a ser referenciado, ou seja, a descoberta, em 1917, relatada por Afonso de E. Taunay, então diretor do Museu Paulista, de uma planta cartográfica, referida como o Mappa de Dom Luis de Céspedes Xeria (1,89 m x 0,79 m, original aquarelado e colorido), existente no Archivo General de Indias, localizado em Sevilha, na Espanha.

Empolgado com a descoberta, relatada inicialmente por Pastells em $1912^{18}$, Taunay tratou de divulgá-la, incluindo-a na Collectanea de mappas de cartographia paulista antiga, organizada por ele e publicada no ano de comemoração do centenário de Independência do Brasil, em 1922.

Em relação ao mapa existente na Collectanea, observa-se que a descrição analítica inicial de Taunay é, de certa forma, um pouco preconceituosa com o trato do material do período: "Este mappa, mero roteiro ou topographia, como no tempo se chamava, é talvez a mais antiga carta conhecida de penetração do Brasil e, certamente o primeiro documento da nomenclatura geographica do planalto"19. Ao atribuir ao valioso documento a definição de "mero roteiro", Taunay projeta sua memória cultural (formada na transição do século XIX para o século XX) em uma representação cultural criada durante o século XVII. Três séculos separam, do analisador, o produto histórico-cultural. E, nesse descompasso de culturas, observam-se as falhas estruturais do processo de análise estabelecido por Taunay.

A divulgação do mapa, na Colletânea de Taunay, vai marcar o imaginário da História Paulista, ou seja, no momento de sua publicação, estabeleciase a percepção da história local associada ao grande desenvolvimento econômico e material advindo com o ciclo do café. Qualquer patrimônio, tangível ou intangível, que apontasse para justificar ações grandiosas, também no passado, serviria para enaltecer ainda mais o presente daqueles que o analisavam e o divulgavam. Nesse sentido, qualquer documentação que retratasse a região do planalto de Piratininga (e fosse anterior ao século XIX) tornar-se-ia ícone de referência e de louvor.

Seguindo tal critério, torna-se claro porque, para Taunay, esse mapa é um "mero roteiro", definição simples, adequada para caracterizar os produtos históricos que não estivessem à altura do modelo historiográfico em desenvolvimento.

mapa de Céspedes Xeria é descrito por Taunay de forma a mostrar a simplicidade do documento, e, em sua visão de análise: "Nelle se veêm o
17. Ver Reverendo Padre Pablo Pastells (1912, p. 422423).

18. Ibidem

19. Ver Affonso de E. Taunay (1922a, p. 3). 
delineamento, do curso do Tietê e do Paraná. Não há ideia de escala, proporções, coordenadas geographicas, nem accidentes orográphicos, ou quaesquer outros. Nem siquer se lembrou o topógrafo de conservar certa relação entre os volumes dos dois rios"20 (Figura 1).

Claro é que o mapa de Céspedes Xeria não poderia ter sido realizado ao gosto estético-científico de Taunay - é produto do momento da expedição, construído pela observação participativa dos membros da comitiva de Dom Luiz C. Xeria a caminho do Paraguai. Observa-se diretamente, neste aspecto, a herança cultural dos exploradores do sertão do país no período, ou seja, a associação, daquilo que é visualizado - desconhecido -, com aquilo que é conhecido e já presente no imaginário em vigor. As proporções dos rios explorados não são necessárias: e o seriam somente se, no decorrer do processo da viagem, fosse encontrada uma passagem que facilitasse ou dificultasse a navegação, ou um outro elemento significativo que não fosse de conhecimento imediato dos exploradores.

Tal modelo cartográfico era confeccionado com o propósito da navegação e do caminho possível de penetração, sendo embasado pelas informações

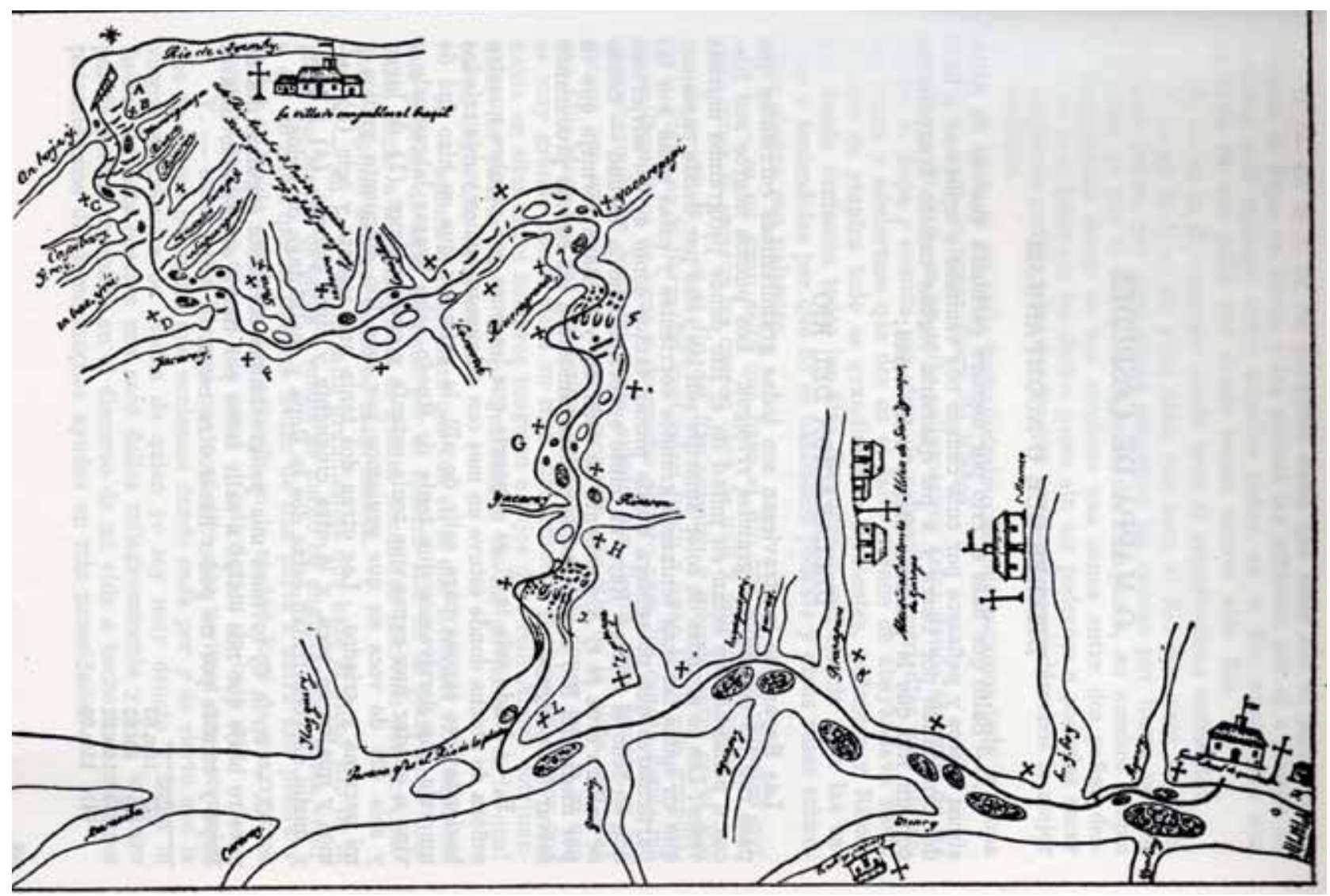

Figura 1 - Reprodução impressa do Mapa de Dom Luiz de Céspedes Xeria, 1628. Fonte: Affonso de E. Taunay (1922). 
in loco e também por batedores e guias já versados nos perigos da travessia. Aqui, a herança cabocla manifesta-se na reprodução dos valores culturais dos habitantes originais do território. Já a herança europeia traduz-se pela aculturação forçada do elemento indígena - e, no mapa original de Xeria, o que se observa é um momento de transição cultural, quando o saber europeu se encontra em fase de substituição gradativa desses valores originais.

No caso, percebe-se que o mapa não pode ser considerado produto de uma exploração pioneira. Ele só é pioneiro ao passar para o papel aquilo que já se conhecia nos relatos orais do período, sem com isso negar que seja um dos poucos resultados de inúmeras expedições anônimas que já haviam sido realizadas na época - a princípio de forma milenar pelos nativos e, posteriormente, de igual forma, pelos colonizadores ${ }^{21}$.

Quanto à caracterização estética da obra, a mesma opinião de Taunay é compartilhada por Sérgio Buarque de Holanda, ao afirmar ser a grande maioria dos mapas deste momento histórico do Brasil lem especial os do território paulista), produzidos até o século XVIII, composta de "toscos desenhos" com "nomes estropiados" 22 , como já citado.

$\bigcirc$ relato de Holanda, já citado anteriormente, ampara-se na forma tradicional de perceber-se o documento histórico - no caso, o cartográfico - nesse momento do pensamento historiográfico nacional. Até então le mesmo em épocas posteriores próximas), o documento não textual sempre era visto como um simples auxiliar do texto histórico e, na análise desenvolvida por Taunay, tal fato não é uma exceção ${ }^{23}$.

Junto com esse olhar analítico de Taunay, também a percepção da cartografia do período não encontrou o correto respaldo científico que deveria ter tido. Na narrativa da coleta do objeto cartográfico, pode-se ler: "Foi copiado para o Museu Paulista pelo hábil cartographo, Snr Santiago Monteiro Diaz, em 1917, a mandado nosso. Ehxumou-o do archivo sevilhano o erudito Pablo Pastell na sua Historia de la Compañia de Jesus em la Província del Paraguay ${ }^{24}$.

No processo de coleta, nota-se que o desenho da então Vila de São Paulo - que aparece timidamente no local que se convencionou classificar como canto superior esquerdo do mapa -, após sua publicação na Colletânea, passou a ser considerada o marco simbólico da representação da urbe paulista em sua fase embrionária. A denominação de "canto superior esquerdo" é uma convenção erudita, pois o mapa não acusa uma rosa dos ventos, nem sequer uma seta indicativa da direção norte. Ele só é compreendido por quem o vivencia ao navegar o rio - ou seja, no momento de sua confecção, o mapa não tinha um sentido ocidentalizado tradicional de leitura, pois ainda preserva valores da cultura local.

Deve-se recordar que a classificação "canto superior esquerdo" relaciona-se à escolha visual adquirida para um objeto cartográfico, ou seja, ele é visualizado pela perspectiva da representação da então Vila de São Paulo, fato que condiciona o leitor a perceber de imediato a razão daquilo que é representado em função, talvez, das escolhas, e seleção, atribuídas por Taunay. Tal escolha de visualização também foi condicionada pela forma como são apresenta-
21. De período posterior, mas ainda apresentando esta forma de compreender o território, há o importante relato de Teotônio José Juzarte. Sob forma de um relatório de campo, ele descreve todo o cotidiano das monções paulistas em seu manuscrito conhecido como Diário da Navegação. Ver Jonas Soares de Souza e Miyoko Makino (2000).

22. Ver Sérgio B. de Holanda (1995, p. 19).

23. Ver Airton, J. Cavenaghi (2006).

24. Cf. Affonso de E. Taunay (1922a, p. 3). 
25. Agradeço a Yolanda Barraycoa Martinez, aluna do curso de graduação em Hotelaria, da Universidade Anhembi Morumbi (SP), pela imprescindível ajuda na realização da coleta documental apresentada. das as legendas indicativas dos desenhos confeccionados, além da do texto explicativo.

Ao fato, associa-se, ainda, que essa mesma representação da urbe foi alterada, para acomodar, ainda mais, a proposta visual seletiva acolhida por Taunay. Originalmente, no mapa original de Xeria, percebe-se que a representação da Vila de São Paulo é, de fato, parte estrutural de todo o conjunto do mapa; e não o objeto principal de sua representação - que efetivamente está associada, quase que exclusivamente, ao mapeamento dos caminhos fluviais apresentados e suas margens. Já no momento da reprodução do mapa, em 1922, como se quer demonstrar a seguir, a cópia focalizou a cidade (outrora vila) de São Paulo e a sua representação iconográfica.

Finalmente era encontrada uma imagem da cidade de São Paulo, da época inicial de sua colonização - fato que, associado às efemérides de comemoração do centenário da Independência do Brasil, ficaria marcado como um grande acontecimento histórico, científico e documental.

Como conciliar a grande descoberta do mapa e a presença de um desenho da cidade de São Paulo de forma satisfatória aos interesses hegemônicos da historiografia do período? A resposta foi aparentemente simples: enaltecer a imagem coletada. Alguém modificou o desenho representativo da vila que está registrada no original, invertendo a posição em que se encontrava, e acrescentou um anexo, uma nova estrutura arquitetônica, à suposta Casa da Câmara que nele havia. Talvez esse fato tenha ocorrido ou por ação do próprio cartógrafo indicado por Taunay, o senhor Santiago Monteiro Diaz, ou por iniciativa direta de Taunay. Nota-se que não houve modificações no restante do mapa (figuras e legendas) copiado pelo cartógrafo. Tal fato corrobora a hipótese de que a mudança - exclusiva - no desenho e legenda relacionados à representação da Vila de São Paulo ajudava à manutenção da ideia de que São Paulo já havia nascido predestinada a ser o centro decisório da história do país. Neste momento, e de maneira sutil, a representação passa a atender os interesses propostos da historiografia paulista em desenvolvimento no período.

No mapa original - o que está na Espanha, no Archivo General de Indias, em Sevilha -, o desenho da Vila de São Paulo encontra-se como na Figura $2^{25}$.

Percebe-se que a estrutura arquitetônica da Vila de São Paulo desenhada pelo cartógrafo em 1628 é apenas situacional, ou seja, representa, em relação ao restante do mapa, indicação de um determinado local que, na visão do desenhista, era apenas parte do caminho a ser percorrido. Nenhum destaque especial é dado à presença da Vila de São Paulo, reconhecida quase que exclusivamente pela legenda "Villa de S. Pablo enel Brasil". Observa-se, também, que, originalmente, a imagem da suposta Casa da Câmara encontra-se, dentro da direção de leitura predominante na escrita do mapa, de ponta cabeça. Tal fato ajuda a corroborar a ideia de ser sua presença um elemento aparentemente secundário no contexło geral do mapa originalmente produzido, ou simplesmente um indicativo do local de saída da expedição de Xeria em 1628. 


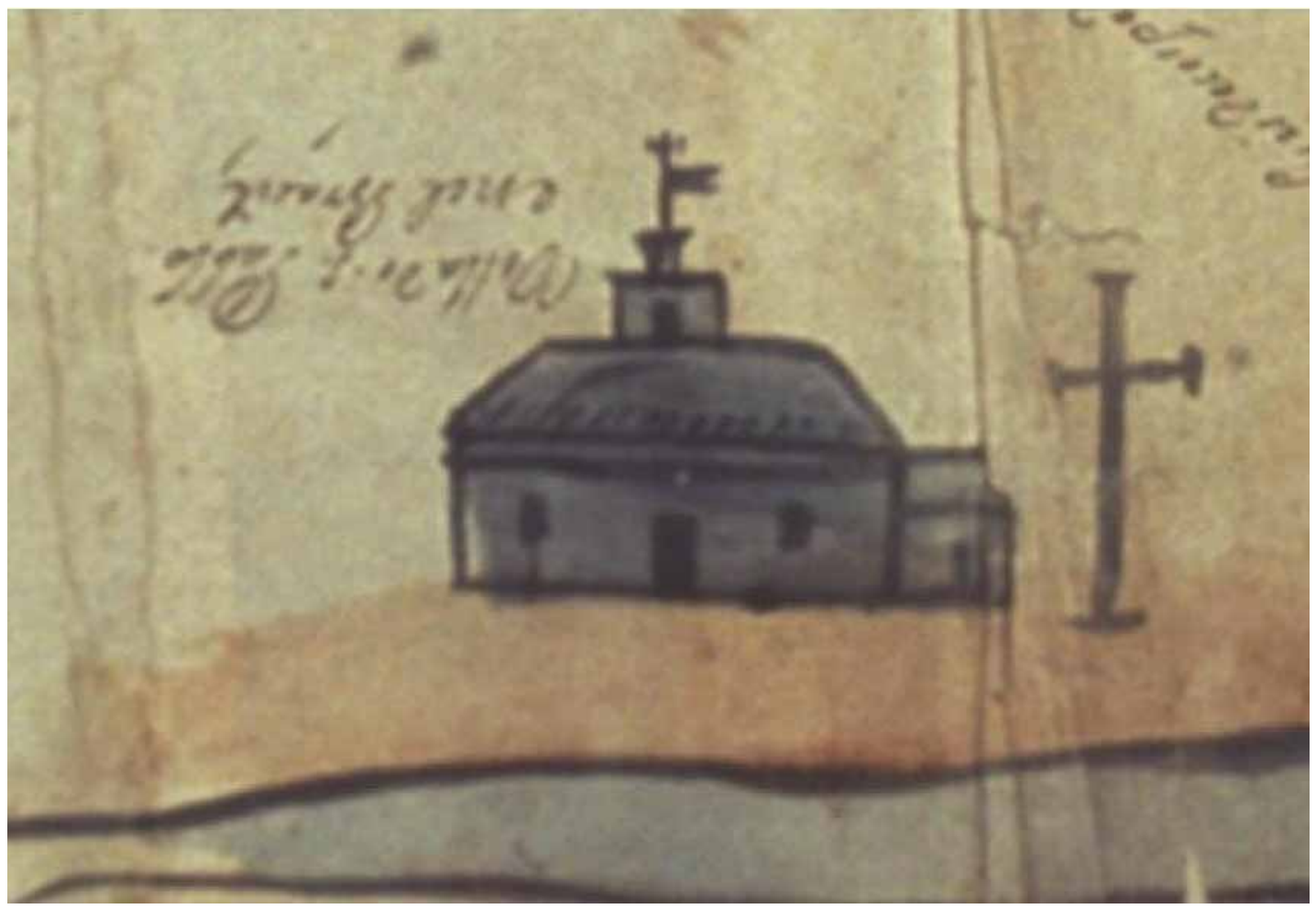

Figura 2 - Detalhe do Mapa del Río Ayembí, que recorrió el Gobernador del Paraguay, D. Luis de Céspedes Jeria al entrar en su Gobernación por la via del Brasil (1628). Archivo General de Indias, Sevilla, España.

Na análise geral do mapa original de Céspedes Xeria, é possível observar que não há qualquer destaque absoluto à então Vila de São Paulo. A imagem de sua representação é secundária no contexto geral da cartografia produzida e representa, apenas, um elemento a mais na estrutura do conjunto. A então Vila de São Paulo, aparentemente, é a via de entrada no percurso mapeado e está, por convenção dos elementos manuscritos no mapa, no que se pode considerar a parte "de cima" do desenho efetuado. O sentido da leitura do manancial escrito torna-se a convenção pictórica associada ao desenho. Assim, pela observação ocidentalizada, o lugar da presença da Vila de São Paulo tornase a "parte de cima" do objeto cartográfico (Figura 3).

Ao observar-se o desenho copiado para a coletânea organizada por Taunay e efetuando-se o detalhe correspondente da imagem mostrado na Figura 2, percebem-se diferenças significativas.

Nota-se, na Figura 4, que a imagem está colocada de forma não invertida, de maneira a facilitar o olhar do observador externo (ao ponto de vista de navegação do cartógrafo do original) e conduzi-lo a perceber a intenção principal do processo pretendido: a futura cidade de São Paulo seria, talvez em um desejo necessário a Taunay, mais importante do que o restante do mapa de Céspedes Xeria. Associado a isso, inclui-se ainda, no desenho da edificação representada - que provavelmente seria a da Casa da Câmara -, em seu lado

Annals of Museu Paulista. v. 19. n.1. Jan.-June 2011. 
Figura 3 -. Mapa del Río Ayembí, que recorrió el Gobernador del Paraguay, D. Luis de Céspedes Jeria al entrar en su Gobernación por la via del Brasil (1628). Archivo General de Indias, Sevilha, Espanha. Note-se a representação da Vila de São Paulo no alto, "de cabeça para baixo".

Figura 4 - Detalhe do Mappa de Céspedes Xeria. Reprodução existente na Collectanea de mappas de cartographia paulista antiga, obra organizada por Taunay (1922).
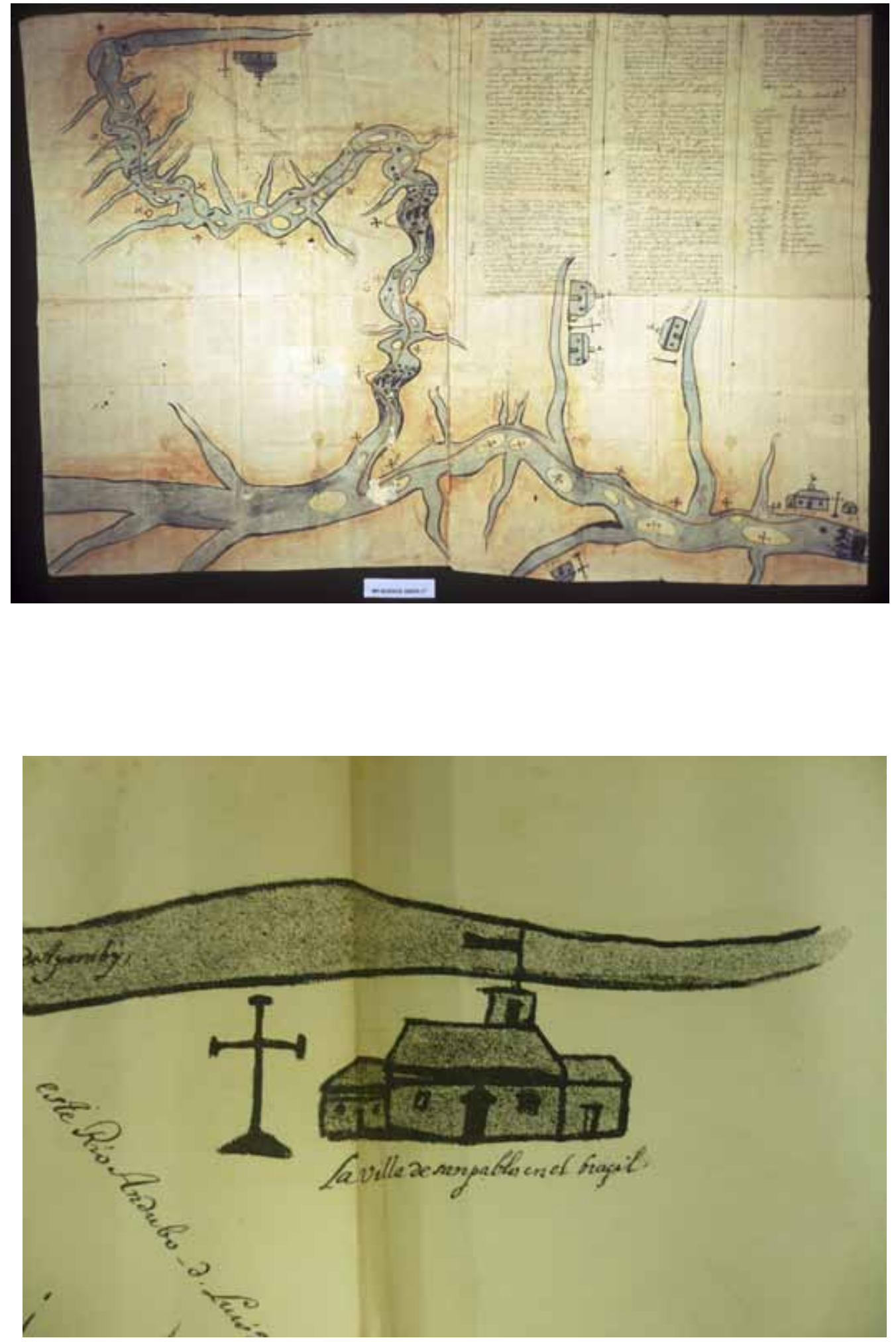
esquerdo, conforme já comentado, outro anexo do edifício, advindo, provavelmente, das considerações de Taunay a respeito da história embrionária da urbe.

Essa "sutil" inclusão aumentou o campo visual de percepção do desenho, facilitando ainda mais sua visualização por parte do observador. $\mathrm{Na}$ porta principal da edificação observa-se, ainda, o batente de forma abaulada. No mapa original de Xeria, no desenho do mesmo batente de porta, percebe-se que ele é reto, típico das casas térreas da época bandeirante.

batente abaulado, inserido pelo desenhista na estrutura da porta, era encontrado, principalmente, em sobrados paulistas do século XVIII, conforme pode ser observado, por exemplo, em fotografias ainda existentes, confeccionadas por Militão Augusto de Azevedo, de edifícios urbanos paulistanos entre 1860 e $1862^{26}$. No desenho original de Xeria, a presença do batente reto e simples podia indicar o pouco luxo das edificações paulista anteriores ao século XVIII. Mas a modificação do formato do batente pode, ainda, reforçar que a maneira de se representar a Vila de São Paulo sofreu alterações propositais, para reforçar as análises históricas do período, propostas por Taunay.

Tal processo complementa-se na questão da legenda, como se pode ver, também modificada para "La villa de San Pablo en el Brazil"27, tentando referenciar, ainda mais, o destaque à expressão de um necessário passado de glórias, buscado de forma constante por Taunay e seus seguidores.

A primeira discussão mais concreta relacionada à representação das residências existentes na cartografia reproduzida por Taunay é feita em 1939, quando Belmonte (pseudônimo de Benedito Carneiro Bastos Barreto) publica No tempo dos Bandeirantes. A obra é fartamente ilustrada pelo próprio Belmonte e, em uma das análises efetuadas, o autor aponta para "um problema da iconografia seiscentista"28, e esclarece qual o problema ao argumentar:

Todos nós sabemos o quanto é pobre a iconografia paulista. [...] a iconografia seiscentista de São Paulo é de um pauperismo acabrunhante, pois não conseguiu sair do âmbito restrito da cartografia e de uma ou outra gravura [...] Entre essa escassa documentação, acha-se o roteiro cartográfico de Dom Luiz de Céspedes Xeria [... . A vila de São Paulo que ali figura, representada por um prédio de três corpos, é a cópia exata de uma casa da cidade ou, apenas, uma representação simbólica da vila?̣29

autor discute se a representação desenhada seria ou não a Câmara da Vila de São Paulo, absorvendo os valores ilustrados no mapa reproduzido por Taunay, ao argumentar que a suposta imagem da Câmara da Vila era "representada por um prédio de três corpos"30.

Não é analisada a autenticidade do material primário, nem mesmo questionada, pois já na época da publicação do livro de Belmonte, em 1939, a legitimidade da documentação recolhida por Taunay era mais que confirmada pela academia, e este academicismo se encontrava representado diretamente na própria figura de Taunay.

A curiosa discussão de Belmonte e Taunay - relacionada a ser ou não a representação da Casa da Câmara no desenho do mapa de Xeria - foi bastante acalorada, e motivou, inclusive, duas respostas de Taunay, em cartas publicadas
26. Esta análise é realizada pela perspectiva do documental iconográfico que José Wasth Rodrigues utilizou entre 1918 e 1920; ver José Wasth Rodrigues (1979, p. 9); sobre os antigos sobrados paulistanos, ver Paulo César Garcez Marins (2004, p. 128-130)

27. Grifo nosso.

28. Ver Benedito Carneiro Bastos Barreto (1980, p. 275).

29. Idem, p. 278-279.

30. Idem, p. 279. 
31. Ver Affonso de E. Taunay (1938a, p. 8); grifo nosso. no jornal Folha da Manhã de então, em exemplares de abril e maio de 1938. Nelas, ao tentar persuadir Belmonte da verdade de suas ideias iniciais, Taunay se justifica, comentando, no primeiro artigo publicado no jornal:

Pensam ambos [Belmonte e Aureliano Leite] que se trata de mera convenção de desenho topographico no rude roteiro do capitão general hespanhol, opinião de que não compartilho [...]. Quando em 1917, o eminente Pablo Pastells me assignalou a presença do mappa de Cespedes, no Archivo General de Indias em Sevilha, e m'o descreveu, soffregamente o fiz copiar fac-similarmente. Dei-me logo pressa em divulgar este documento preciosissimo, onde se insere, o até hoje, mais antigo elemento conhecido da iconographia paulistana.

Attribui entao à figurinha cespediana a circumstancia de que devia representar a cãs do concelho piratiningano naquelle millesimo longínquo. Casa do Concelho e não senado da Câmara como Belmonte, por descuido, escreveu, pois só depois de 1711 com a elevação a cidade, passou São Paulo a ter senadores em vez de officiaes da câmara [...] Negando que a casa figurada na estampa do mappa epigraphada "la villa de san pablo em el Brasil" possa ser o paço do concelho paulistano não passando de mera convenção do desenho, aponta Belmonte " a sua semelhança com as figuras que occorrem no mesmo mappa assignaladoras das reducções jesuitas da Villa Rica e de Gauyrá. Há ahi profundo equivoco [...] Observando as tres figurinhas de edificios taes como as que Céspedes assignala para fixar as três municipalidades de "San Pablo en el Brasil". Villa Rica e Ciudad Real de Guairás (sic) vemos que ellas obedecem á mesma converção. Todas têm, sobre o telhado, uma espécie de sótão na parte posterior do desenho, onde se alça um mastro com bandeira desfraldada. Ora o facto da presença da bandeira no prédio é o mais frisante característico de edifício publico [...] Não é crível que semelhantes casinhas tenham sido igrejas. [...] No mais São Paulo apresenta um corpo principal com dois annexos, á direita e á esquerda, Ciudad Real uma casa maior, tendo ao lado outra menor, não contígua; Villa Rica uma casa apenas, do tamanho da maior de Ciudad Real. Assim também, não são idênticos os desenhos convencionaes das ditas reducções. Um apresenta uma casinha isolada, e o outro uma casinha com puxado. Há, pois, na série das cinco figurinhas de Céspedes dois typos de construcção: um com sótão mastro e bandeira, parece representar as três edilidades, outro sem sótão, mastro nem bandeira, designa as reducções jesuíticas ${ }^{31}$.

É perceptível, nessa afirmação, que os acréscimos ao desenho que representa a Vila de São Paulo de então são considerados como legítimos, e sequer são apresentadas hipóteses de sua falsificação. Belmonte estava certo em questionar o que via no mapa - apenas não conseguiu perceber as diretrizes reais das abordagens a serem referenciadas. Taunay, em nenhum momento, deixa transparecer que não é um documento fac-similar verossímil que está sendo analisado. Argumenta, inclusive, que "soffregamente o fiz copiar fac-similarmente", ignorando uma suposta falsificação. Teria essa ocorrido à revelia de Taunay? Caso assim seja, por qual razão ela teria sido efetivada?

Pela documentação analisada, nota-se que Taunay não esteve na Espanha para ver o original do mapa. Desta forma, o desenho, considerado por Taunay um fac-simile do mapa de Xeria (mas que na realidade não o é), teria chegado "pronto" ao Brasil; e só assim Taunay o teria visto. Acredita-se que as 
modificações apresentadas tenham ocorrido em tal momento, mas, independente do fato, Taunay continuou a responder às críticas de Belmonte.

Acha o meu erudito contestante por demais pomposo o qualificativo de municipalidade que attribui a Ciudad Real e a Villa Rica, dois arraiaes quando muito.[...] Quanto ao facto dos mastros das casinhas de Céspedes, em São Paulo e nas villas hespanholas, terminarem por cruzetas (o que motiva reparos do meu douto opponente) penso que não há motivos para tal duvida [...]. Isso reforça a hypothese de que as casinholas do mappa assignaladoras das duas reducções de Loreto e Santo Ignácio não devem ter representado igrejas. [...] Entende Belmonte que Céspedes teria collocado no seu mappa pelourinhos e não cruzairas se acaso quizesse caracterisar os paços municipais de São Paulo, Ciudad Real e Villa Rica. Discordo deste modo de ver. $O$ pelourinho além de ser geralmente uma columna de pequena altura constituía, naquelles tempos, verdadeiro poste de infâmia ${ }^{32}$.

Não se dando por vencido, Belmonte responde a cada uma das indagações apresentadas por Taunay, mas suas respostas estão baseadas no mapa reproduzido em 1922. Assim, suas argumentações já reforçam a ideia de ser São Paulo a principal cidade representada, pois, sem a percepção direta do mapa original existente, seria impossível a formulação de um argumento contrário.

\section{mapa de Céspedes Xeria e sua visualização na contemporaneidade}

A reprodução do mapa de Xeria, constantemente replicado desde a sua publicação na Colletânea de Taunay, tornou-se uma espécie de iconografia romântica dos tempos iniciais da cidade de São Paulo. Tal fato, entretanto, provavelmente não ocorreu por intenção principal do copiador, mas, talvez, pela interferência direta de Taunay, que, em sua ansiosa vontade de resgatar o manancial historiográfico paulista, pode ter procurado transformar a vila de então - a do momento da representação no mapa de 1628 - em centro principal das atenções. E isso para uma cidade que, originalmente, era vista apenas como entroncamento de caminhos entre o litoral e o sertão - situação em que o isolamento geográfico, favorecido pela serra do Mar, transformava-a, por exemplo, em local não propício a ser hospitaleiro com os não pertencentes ao seu cotidiano cultural. Ainda hoje, a acumulação de riquezas, na vila de São Paulo, no período da confecção do mapa de Xeria, é elemento de discussões historiográficas interessantes e bastante significativas ${ }^{33}$.

Outro exemplo da herança recebida de muitos dos mapas da Colletânea é a criação de textos historiográficos posteriores, inclusive da historiografia atual, que dão respaldo, nesta situação específica, a essa suposta verdade absoluta propagada por Taunay.

Trabalhos consagrados, pela mídia e pelo público, utilizam-se de mapas apenas como ilustração daquilo que é escrito. Reproduz-se a impressão, quase simplória, de que, para ser absorvida na contemporaneidade, a ciência histórica necessita do elemento pictórico para materializar-se na memória do seu 
34. Para mais detalhes ver, entre outros: Solange Ferraz de Lima e Vânia Carneiro de Carvalho (1997); Boris Kossoy (2001); Airton J. Cavenaghi (2003); e James Roberto da Silva (2009).

35. Ver Sênia Bastos (2006).

36. Em relação à caracterização pictórica da antiga cidade de São Paulo, ver Solange Ferraz de Lima e Vânia Carneiro de Carvalho (1993); ver, também, José Wasth Rodrigues ([195?]). leitor/observador - quase poderíamos chamá-la, às vezes, de uma história pitoresca. Mas cabe lembrar que isso ocorre, também, com qualquer outro tipo de representação imagética, embora a fotografia tenha recebido, nos últimos anos, um tratamento diferenciado, em função da grande quantidade de trabalhos historiográficos de cunho crítico, realizados no Brasil nessa área específica ${ }^{34}$.

A recriação de um manancial iconográfico dos primeiros momentos da colonização portuguesa em terras paulistas tem inicio, principalmente, com o trabalho de José Wasth Rodrigues, que já se destacava, desde 1918, como "pintor do período colonial brasileiro". Encarregado por Taunay de reproduzir le produzir) um manancial iconográfico e histórico do período, em razão das comemorações do Centenário da Independência do Brasil, as pinturas de Wasth Rodrigues incorporaram, visualmente, a suposta realidade histórica necessária à concretização do pensamento historiográfico compartilhado por Taunay ${ }^{35}$.

A obra e o trabalho desse pintor ganham força e representação, atingindo seu período de maior divulgação nas comemorações do IV Centenário da cidade de São Paulo. Nesse momento, por exemplo, é lançada uma coleção com 25 estampas realizadas pelo pintor, a partir de fotografias existentes na coleção do Museu Paulista. Uma dessas estampas mostra a suposta Casa da Câmara lidentificada por Taunay no corpo da reprodução do mapa de Céspedes Xeria) e é fruto de quadro pintado, em 1920, para o Museu Paulista, por encomenda do próprio Taunay (Figura 5) 36 .

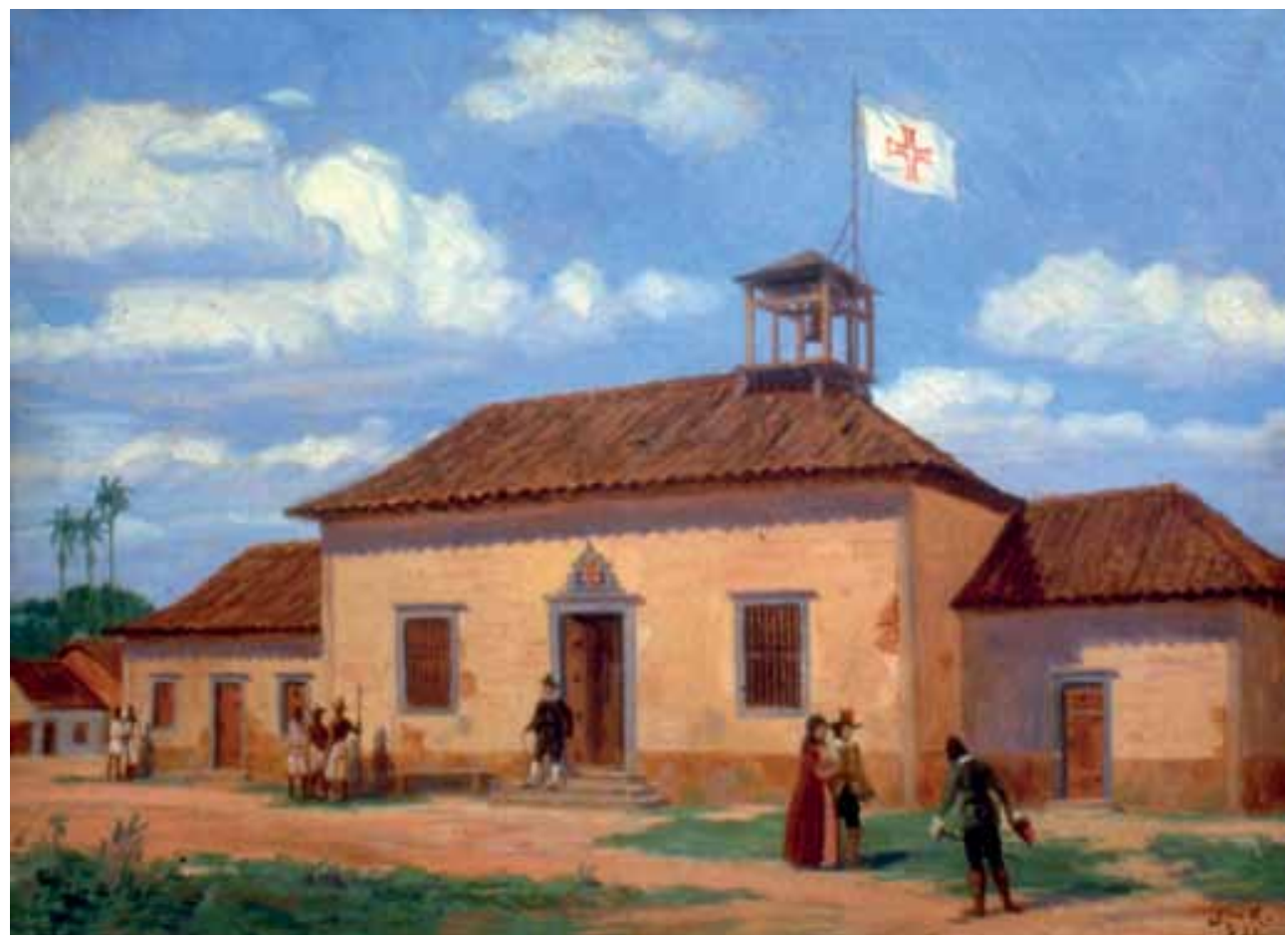

Figura 5 - José Wasth Rodrigues. Paço Municipal em 1628 (1920). Óleo sobre tela, 75,5 cm x $100 \mathrm{~cm}$. Acervo do Museu Paulista (São Paulo, SP). 
Nesse momento, o imaginário inicial - relacionado à caracterização da então Vila de São Paulo apresentada na reprodução do mapa da expedição de Xeria - é incorporado definitivamente como modelo imagético de representação da São Paulo colonial.

A suposta imagem da Casa da Câmara assume uma identidade perdida mas necessária - para legitimar um inconsciente coletivo de representação da "força paulista".

A imagem, utilizada por J. Wasth Rodrigues em suas aquarelas, passa a ser obrigatória para ilustrar outras publicações com fins diversos, como a reprodução da página do Atlas Histórico Escolar, editado pelo MEC/Fename (Figura 6), onde se nota de imediato a recriação do imaginário difundido pelo

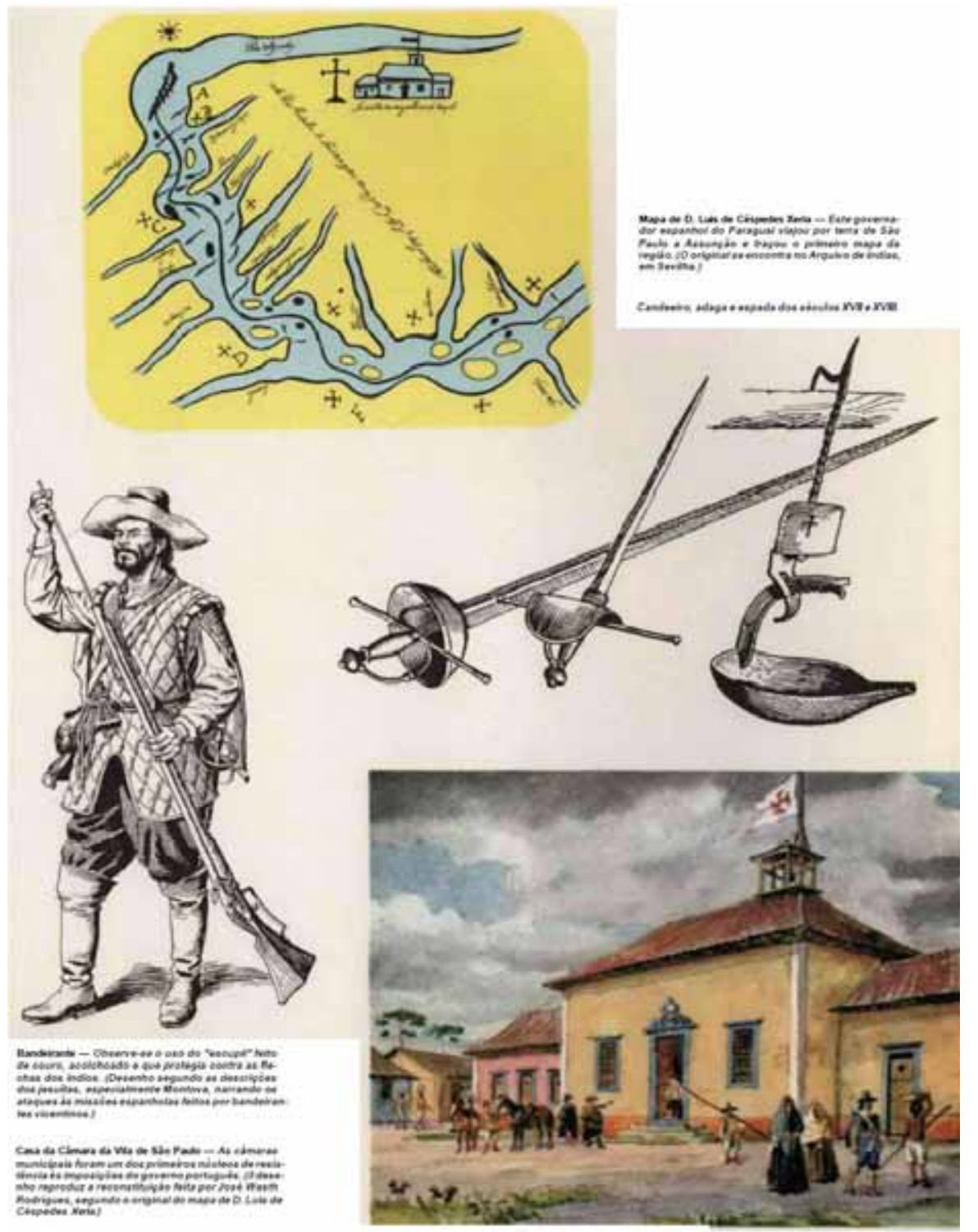

Figura 6 - Reprodução de página do Atlas escolar organizado por Manoel M. Albuquerque, Arthur C. F. Reis e Delgado de Carvalho (1977, p. 23). 
37. "Pequenos compartimentos construídos no alto das edificações com a intenção de aproveitar o desvão do telhado e às vezes servindo com observatório. Em algumas cidades de clima mais quente, a sua função era de refrigerar o ambiente interno"; ver José Geraldo Simões Junior (1997)

38. Ver Raul Duarte (1941) desenho do mapa divulgado por Taunay. Ao lado esquerdo da suposta Casa da Câmara, há um anexo que não consta no mapa original de Xeria, mas existe no mapa da Colletânea de Taunay. Além desse fato, na aquarela de Rodrigues, a torre existente na representação da Casa da Câmara suporta um sino - elemento não presente, sequer sugerido, nas representações do original seiscentista. Podese supor que tal elemento arquitetônico (a "torre") poderia ser uma "camarinha" 37, típica das construções bandeirantes existentes no território paulista (séculos XVII e XVIIII.

A representação corroborada por Taunay ganha então espaço e perpetua-se como imaginário que identifica a região paulista durante seu período inicial de colonização.

Na imagem da página do Atlas MEC/Fename lque em 1977 já estava em sua sétima edição), é possível perceber, de forma nítida, como a verdade atribuída à reprodução do mapa de Xeria já havia se concretizado e desenvolvera um referencial imagético até hoje repetido. De maneira pedagógica, o imaginário que brotou da obra de Taunay ganhava o espaço das salas de aulas e moldava, definitivamente, a percepção histórica das crianças e adultos educados naquele período.

Na atualidade, ainda é possível identificar a presença da reprodução do mapa de Céspedes Xeria em diferentes suportes. Daqueles encontrados, consideram-se, aqui, os que, em função de sua forma publicação e distribuição, presumem-se os mais difundidos.

A primeira aparição do contexto do imaginário criado pela propagação do mapa de Céspedes Xeria reproduzido está em São Paulo de ontem e de hoje... ${ }^{38}$ (Figura 7).

Essa obra de crônicas da cidade e de seu cotidiano foi editada em 1941, momento de intensas transformações urbanas na cidade, e distribuída gratuitamente pela Predial Novo Mundo S.A. Nela é possível visualizar uma "interpretação" da suposta Casa da Câmara presente na reprodução publicada em 1922, fartamente comentada por Belmonte e Taunay, e agora inspirada nos desenhos de J. Wasth Rodrigues.

Já em 1954, tem-se a primeira edição de Relatos Monçoeiros, do próprio Afonso de Taunay, que traz detalhes de escritos presentes no mapa de Céspedes Xeria, além de novamente publicar a figura do mapa reproduzido em 1922.

Logo em seguida, é possível encontrar fragmento, do mapa reproduzido, impresso em capas de publicações da Anhambi, que, durante a década de 1950, produziu uma série de livros com essa característica editorial (Figura 8)

Após esse período, tem-se a imagem nas capas da chamada Coleção Paulistica, da qual faz parte, inclusive, a reimpressão da obra de Belmonte, em 1980. A Coleção Paulística foi editada pelo Governo do Estado e, desde a impressão de seu primeiro título, em 1977 (Figura 9), apresenta estampado o Mappa de D. Luis de Céspedes Xeria (a cópia), demonstrando novamente a absorção deste imaginário iconográfico. 


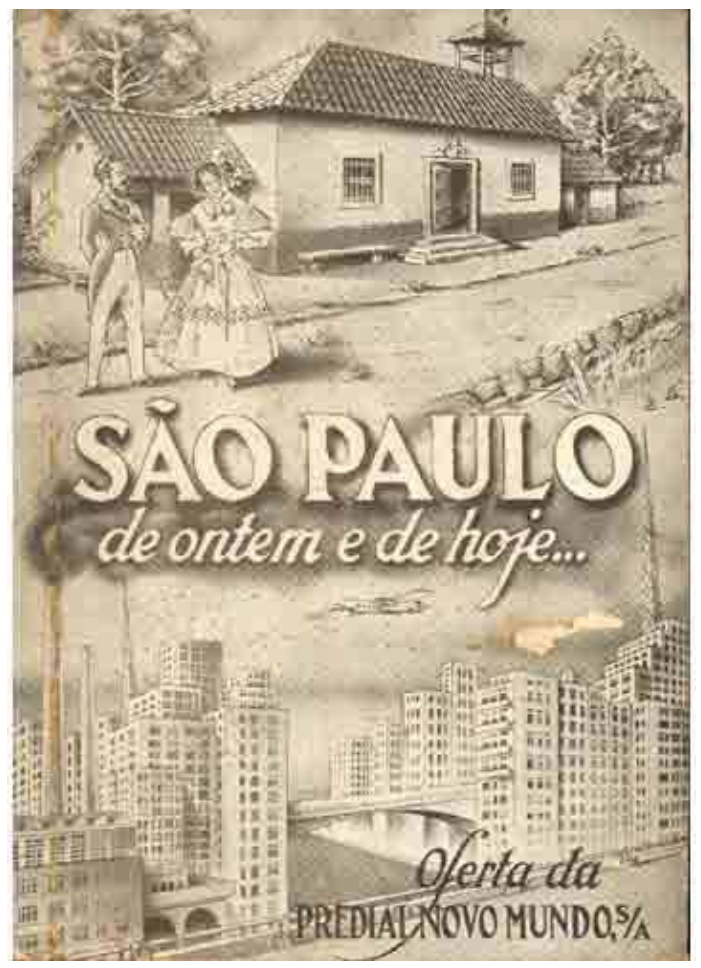

Figura 7 - Capa do livro São Paulo de ontem e de hoje... 12,5 cm x 18,5 cm. Impresso. Fonte: Raul Duarte (1941).

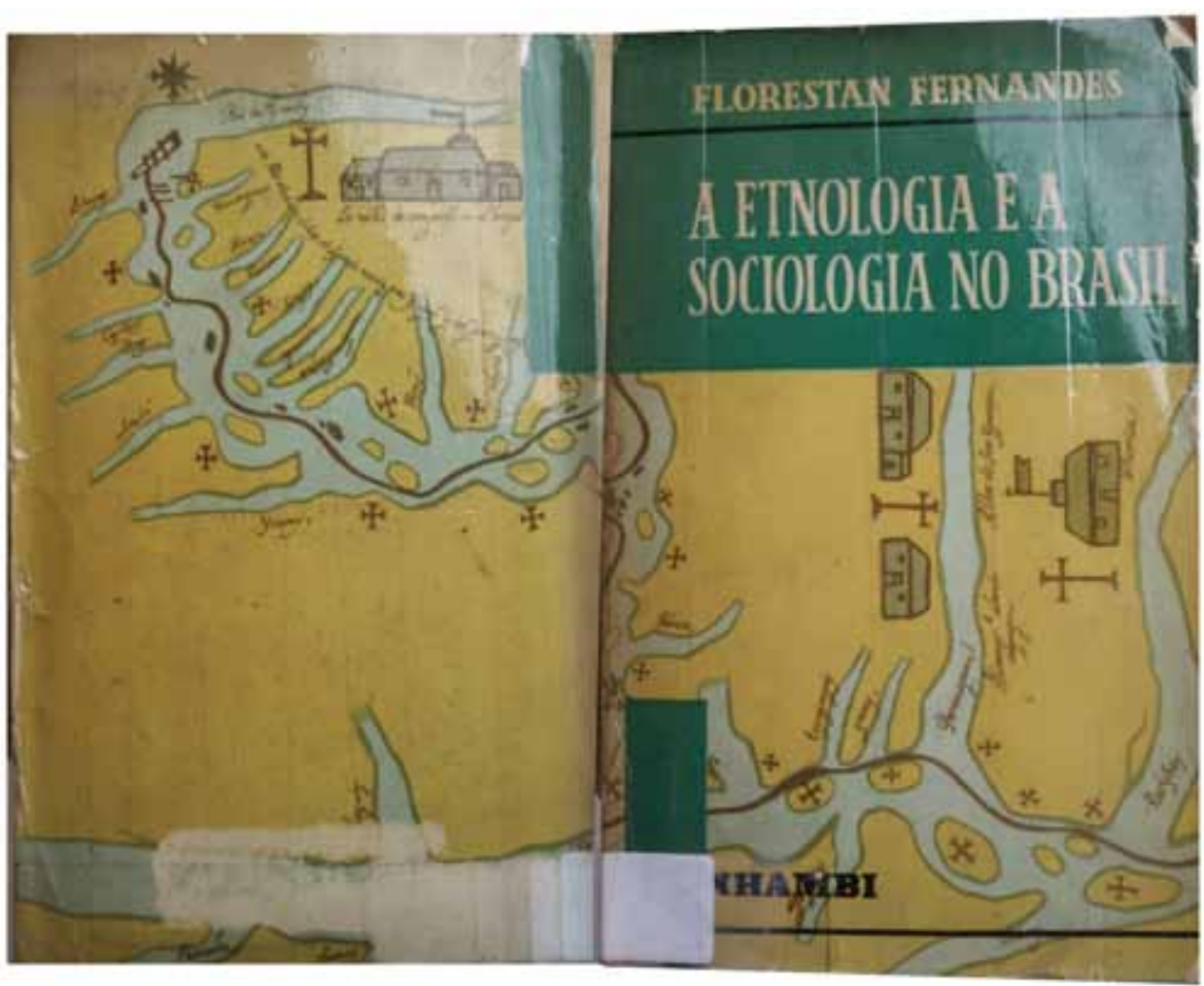

Figura 8 - Capa de A etnologia e a sociologia no Brasil, de Florestan Fernandes (1958). 


\section{COLECAO PAULISTICA}

VOLI

\section{ROTEIROS E NOTÍCIAS DE SÃO PAULO COLONIAL}

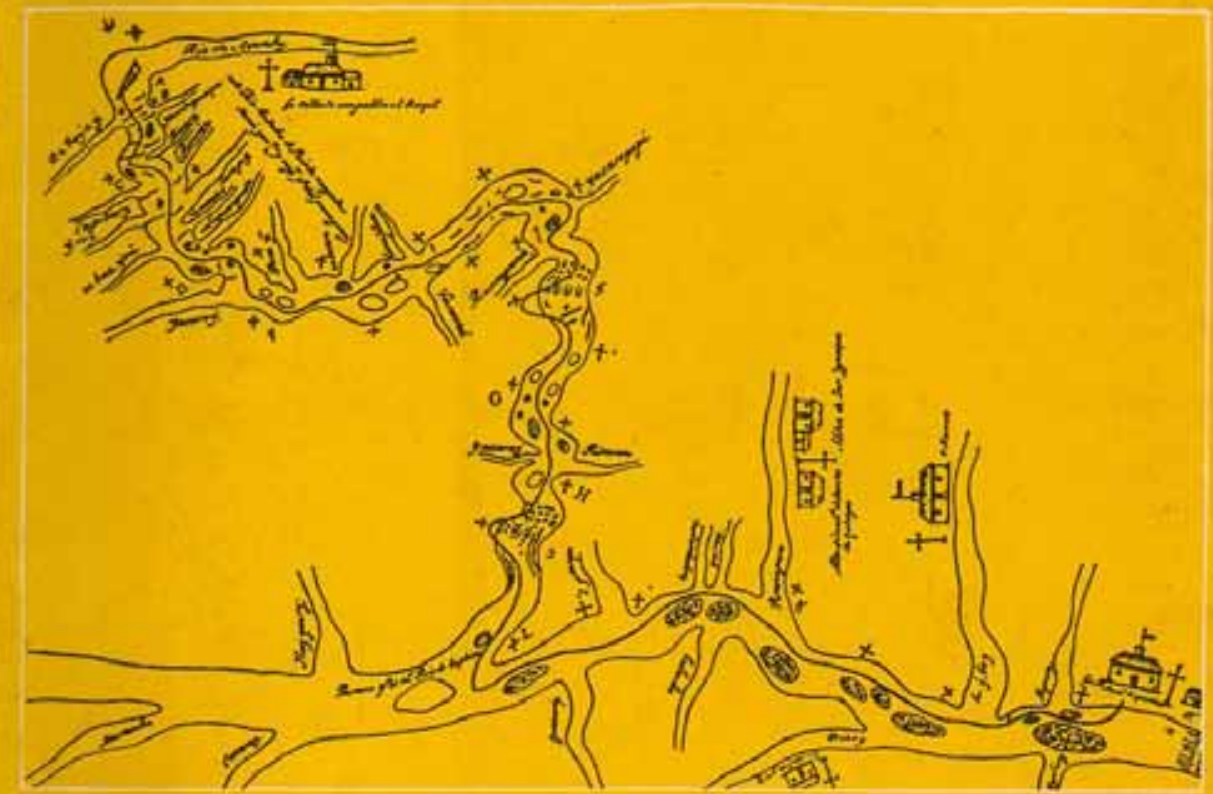

GOVERNO DO ESTADO DESAO PAULO

Figura 9 - Capa de Roteiros e notícias de São Paulo colonial, primeiro volume da Coleção Paulística, Marcelino P. Cleto et al. (1977). 
Na orelha do livro há uma descrição do mapa de Xeria:

Dos antigos roteiros fluviais do Tietê e do Paraná, nenhum é tão velho e pitoresco, sendo ainda a primeira carta conhecida da penetração do Brasil e o primeiro documento existente da nomenclatura geográfica do planalto parananiano - diz Afonso de E. Taunay do mapa de D. Luis de Céspedes Xeria, reproduzido na capa. Desenhado por aquele governador do Paraguai, quando a caminho da sede do seu governo, com tintas e ervas selvagens, para mostrar a seu soberano, Felipe IV, de Espanha, os percalços por ele sofridos na viagem que fez desde "la Villa de San Pablo del Brasil à la Ciudad Real del Guayrá", o original se encontra em Sevilha, no Arquivo [Archivo] General de [...] Indias ${ }^{39}$.

Em se tratando da reprodução do mapa, a ilustração nas capas da coleção Paulística era sempre a mesma, mudando apenas suas cores nos exemplares publicados. Nesse processo, a imagem da então Vila de São Paulo fixa-se no imaginário cotidiano e passa a incorporar um elemento de verdade documental única e inquestionável, principalmente ao associar-se à documentação inédita publicada sobre a história de São Paulo e à imagem (acessível) do mapa de Céspedes Xeria reproduzido em 1922 sob a indicação de Taunay.

Após a publicação dos exemplares da Coleção Paulística, percebe-se um lapso temporal na continuidade da divulgação desse mapa. Entre os anos de 1980 e 2000, não foi encontrada obra editada, ou mesmo outro trabalho acadêmico, que tenha referenciado o mapa de 1628 ou sua reprodução.

Talvez uma das razões diretas esteja na publicação definitiva da reprodução do mapa de Xeria em 1977, na segunda edição da obra de Taunay: Relatos Monçoeiros. Com ampla divulgação, Relatos Monçoeiros - relançado pela editora Itatiaia na série intitulada Reconquista do Brasil -, apresenta a estampa do mapa em preto e banco, além de uma interpretação histórica de Taunay e uma tradução dos seus dizeres. É nesse momento que a imagem se torna elemento praticamente obrigatório para ilustrar qualquer documentação que fosse referenciar o início da ocupação do território paulista e sua história.

Aparentemente, o lapso iniciado após tal publicação é quebrado apenas no ano de 2000, com a crescente produção historiográfica brasileira associada às Comemorações dos 500 anos do "descobrimento" do Brasil. A reprodução do mapa de Céspedes Xeria é novamente utilizada para ilustrar a forma como a historiografia passou a perceber a ocupação das terras paulistas, ou seja, voltam a existir razões significativas tentando demonstrar que a região com maior concentração de renda do país (naquele momento) teve uma formação histórica e iconográfica comparável às representações existentes em outras partes do território brasileiro. $\bigcirc$ mapa torna-se uma espécie de coringa editorial e iconográfico, ou seja, por si só, ele representa a ilustração da ocupação do território desde o século XVI ao inicio do século XVIII.

De forma tímida e inaugurando esta nova fase de exposição da estampa, a reprodução da iconografia do mapa de Xeria reproduzido é encontrada na obra, Diário da Navegação ${ }^{40}$ quando, na Introdução aos escritos de Teotônio José Juzarte, é referenciada a cartografia do rio Tietê, sendo aí
39. Texto sem atribuição de autoria, publicado na orelha, em Marcelino P. Cleto et al (1977).

40. Ver Jonas Soares de Souza e Miyoko Makino (2000, p. 440). 
41 . Como a de Relatos Monçoeiros, por exemplo, em 1977 , pela editora Itatiaia, de Belo Horizonte, em parceria com a Edusp, de São Paulo. estampado um detalhe do mapa existente na Colletânea organizada por Taunay em 1922 (Figura 10).

Neste momento é possível perceber uma recuperação no processo de divulgação da imagem do mapa de Xeria reproduzido por Taunay, não sendo consideradas, nesta análise, as re-edições das obras ja citadas ${ }^{41}$.

Fato semelhante ocorreu com a representação da já tradicional imagem da suposta Casa da Câmara de São Paulo, que continuou a ser reproduzida, principalmente em obras de fins didáticos, para ilustrar textos referentes à ocupação inicial da Capitania de São Paulo.

A imagem da Figura 11 recupera a representação das aquarelas de $J$. Wasth Rodrigues, reiterando a interferência existente no Mappa reproduzido:

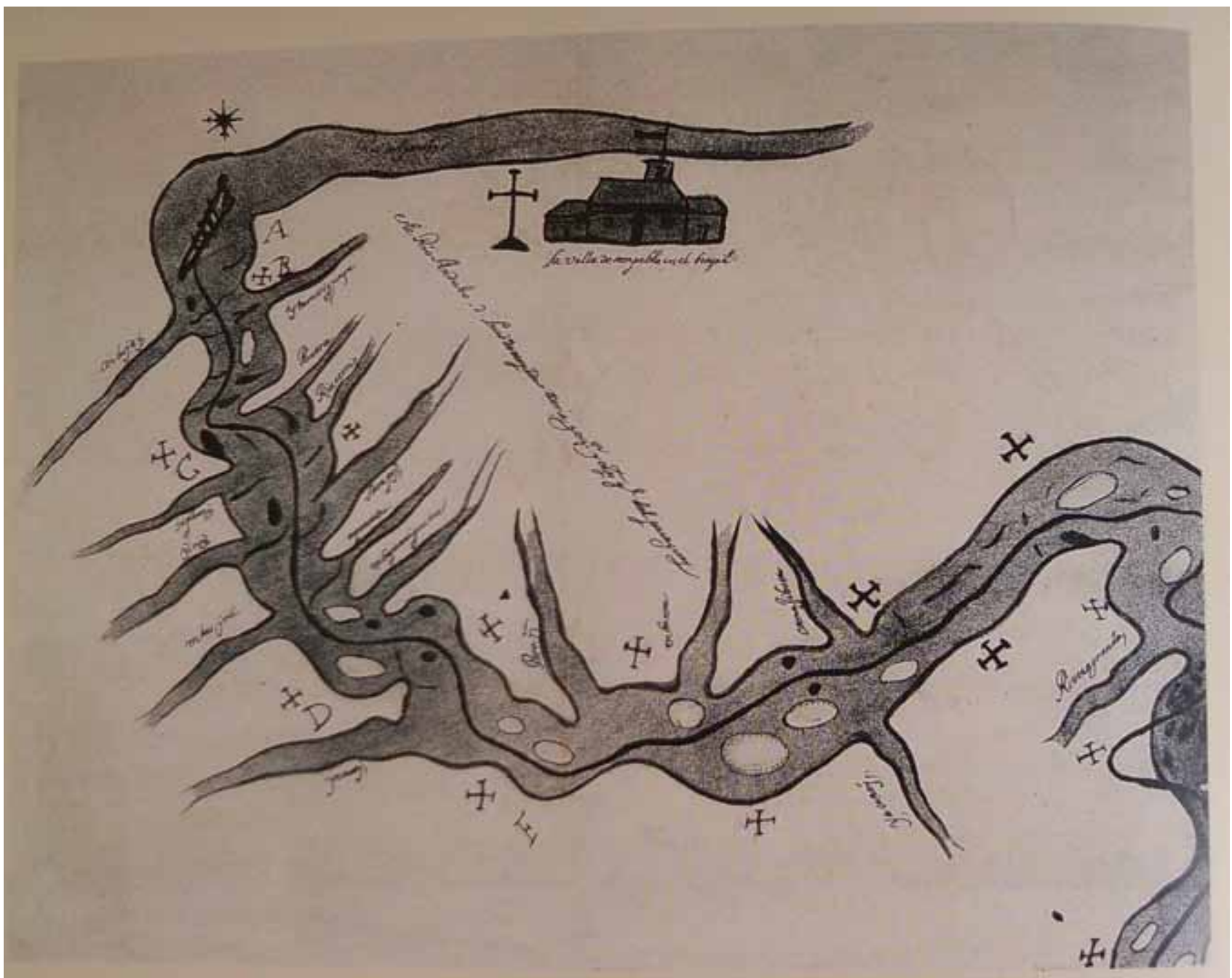

Figura 10 - Detalhe do Mapa de Céspedes Xeria (reprodução de 1917). Fonte: Jonas S. de Souza e Miyoko Makino (2000, p. 440). 
O monopólio do sal e das especiarias manteve-se com a Coroa portuguesa, que procurou, nesses primeiros tempos, criar um conjunto de regras com o objetivo de estimular a iniciativa particular - sem, no entanto, abrir mão da soberania sobre as terras brasileiras.

Durou pouco tempo essa experiência, que dava grandes poderes à iniciativa particular. Apenas duas capitanias, São Vicente e Pernambuco, conseguiram se transformar em importantes centros de produção de açúcar.

A falta de estímulos da Coroa às capitanias, o abandono, a carência de recursos e ainda a resistência indigena foram algumas razōes que obrigaram o Estado português a criar uma estrutura administrativa mais centralizada, na figura de um governador-geral. A ele caberia auxiliar o esforço colonizador das capitanias, combater as rebeliôes indigenas e defender o território das invasōes estrangeiras.

Em 1549, chegava à América Portuguesa o fidalgo português Tomé deSousa, primeiro governador-geral.Junto com ele vinham também osjesuítas, principais responsáveis pela evangelização dos nativos e pela educação na colônia. Aos poucos, os donatários foram perdendo poder para o governador-geral e seus auxiliares: o ouvidor-mor (justiça), o provedor-mor (fazenda) e o capitão-mor (defesa).

Naquele mesmo ano de 1549, Tomé de Sousa fundava a cidade de Salvador, o centro político-administrativo da colônia. Com a formação dos primeiros núcleos urbanos, fazia-se necessário ordenar o poder local. Daf a criação das câmaras municipais, responsáveis pela administração local, obras públicas, regulamentação do comércio e ofícios e abastecimento.

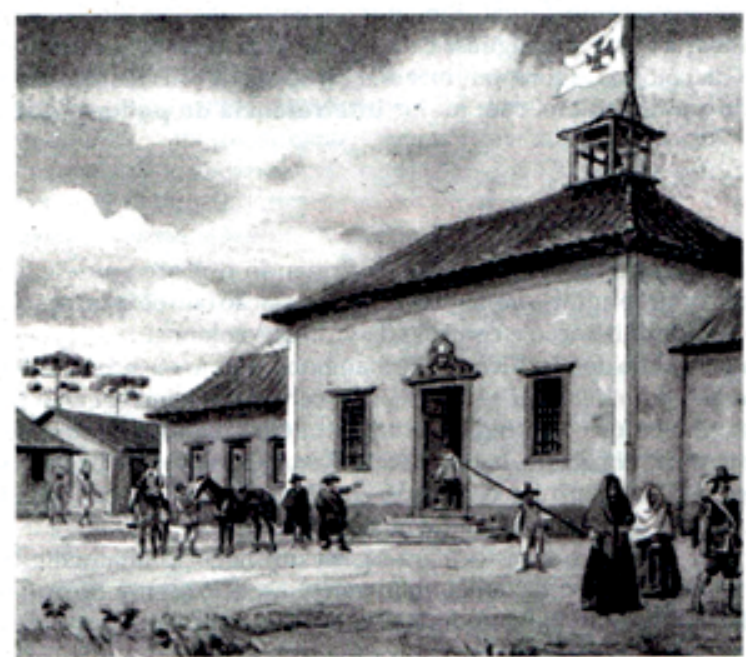

Câmara municipal

As câmaras municipais, que logo se tornaram a base da administração na colônia, eram formadas por membros eleitos por uma assembléia de proprietários locais.

Com o decorrer do tempo, as câmaras transformaram-se em local privilegiado de atuação dos proprietários de terras e de escravos. Esses proprietários, muitas vezes, entraram em choque com os comerciantes portugueses, responsáveis pelos preços dos produtos de exportação.

Figura 11 - Página de fascículo do Telecurso 2000, Fundação Roberto Marinho (1995). 
42. Ver Roberto P. de Toledo (2003).

43. Ver Eduardo Bueno (2004). nota-se, no lado esquerdo da imagem, o anexo inserido ao ser confeccionada a cópia.

Posteriormente, a divulgação dessa imagem ainda é encontrada na contracapa da obra A capital da solidão ${ }^{42}$, lançada pela Objetiva como seu carro-chefe editorial para as comemorações, em 2004, dos 450 anos da cidade de São Paulo (Figura 12). Apesar de no texto não ser diretamente usada a representação cartográfica, tal reprodução da "Câmara" demonstra a permanência direta dessa figura caracterizadora da São Paulo colonial, disseminada pela obra Taunay em 1922, no imaginário associativo da população.

No ano seguinte é lançada a coletânea Os nascimentos de São Paulo ${ }^{43}$, trazendo textos em que se discute o processo inicial de ocupação do planalto de Piratininga. Na inserção do Sumário da obra está a clássica imagem assumida como representação da Vila de São Paulo. Aqui, antes de iniciar a leitura do livro, o leitor é conduzido a perceber o documento mais antigo que se conhece (sobre o locall) associando o manancial escrito a uma ilustração, mesmo que incorreta, do território a ser analisado (Figura 13).

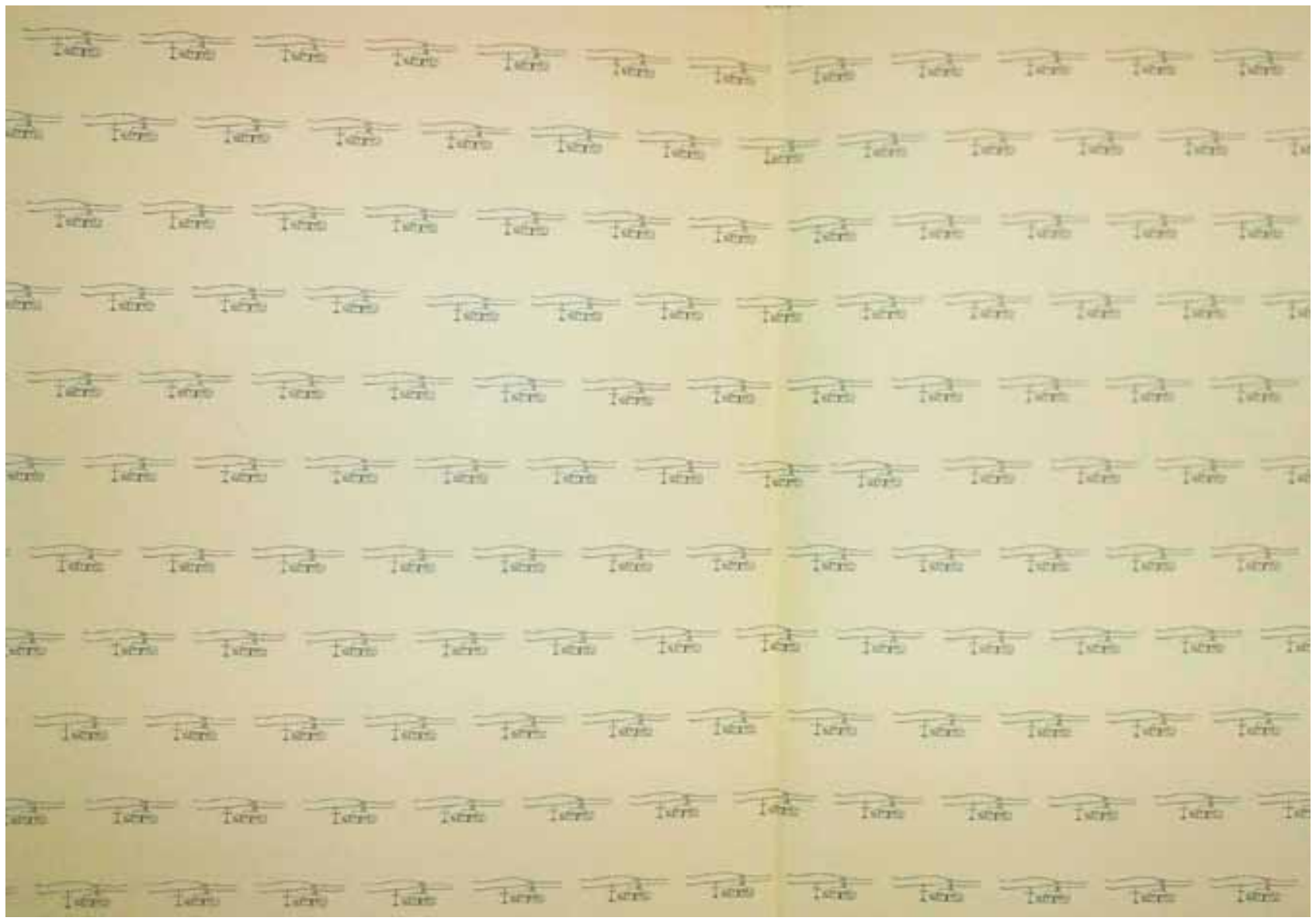

Figura 12 - Contracapa e folha de guarda de A capital da solidão, Roberto P. de Toledo (2003). 


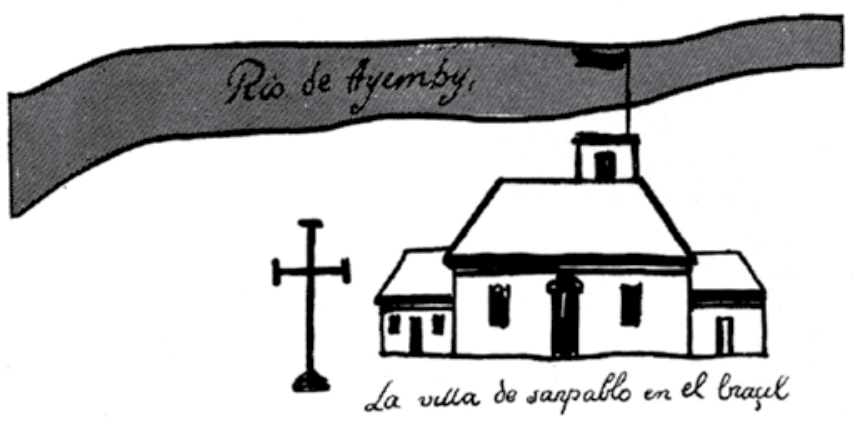

SUMÁRIO

7 Os nascimentos de Sảo Paulo Eduardo Bueno

23 o solo de Piratininga Aziz Ab'Saber

53 OS INDIGENAS do

Planalto Paulista Benedito Prezia

85 Simbolismo e Doutrina NA

fundação de São Paulo Luiz Augusto Kehl

113 o Pátıo do Colégio Maria Aparecida Lomonaco

145 AS MULHERES DO COMEÇO

de São Paulo Hernâni Donato

163 A CONSTRUÇÃO DE UMA

IDENTIDADE PAulista Lilia Moritz Schwarcz

190 O Renascimento modernista de São Paulo

NA DÉCADA DE 1920 Nicolau Sevcenko

206 CRédito das imagens

Figura 13 - Detalhe do Mappa de Céspedes Xeria. Fonte: Eduardo Bueno (2004, p. 5).

Mais recentemente, foi lançada a obra Caminhos da conquista: a formação do espaço brasileiro ${ }^{44}$, em que novamente é referenciado o Mappa de Céspedes Xeria, como reproduzido na obra organizada por Taunay em 1922.

A última e mais recente imagem completa do Mappa de Céspedes Xeria,

44. Ver Vallandro Keating e Ricardo Maranhão (2008).

45. Ver Marcos Antonio Villa (2010).

identificada está em Breve história do estado de São Paulo45, editado em 2010. Aí se encontra, novamente, a imagem tornada tradicional do mapa proveniente da obra de Taunay de 1922.

Em tempos contemporâneos, o mito da formação do povo paulista associado à imagem reproduzida do mapa, incluída por Taunay em sua Colletânea - vem sendo utilizado enquanto icone de representação da Vila de 


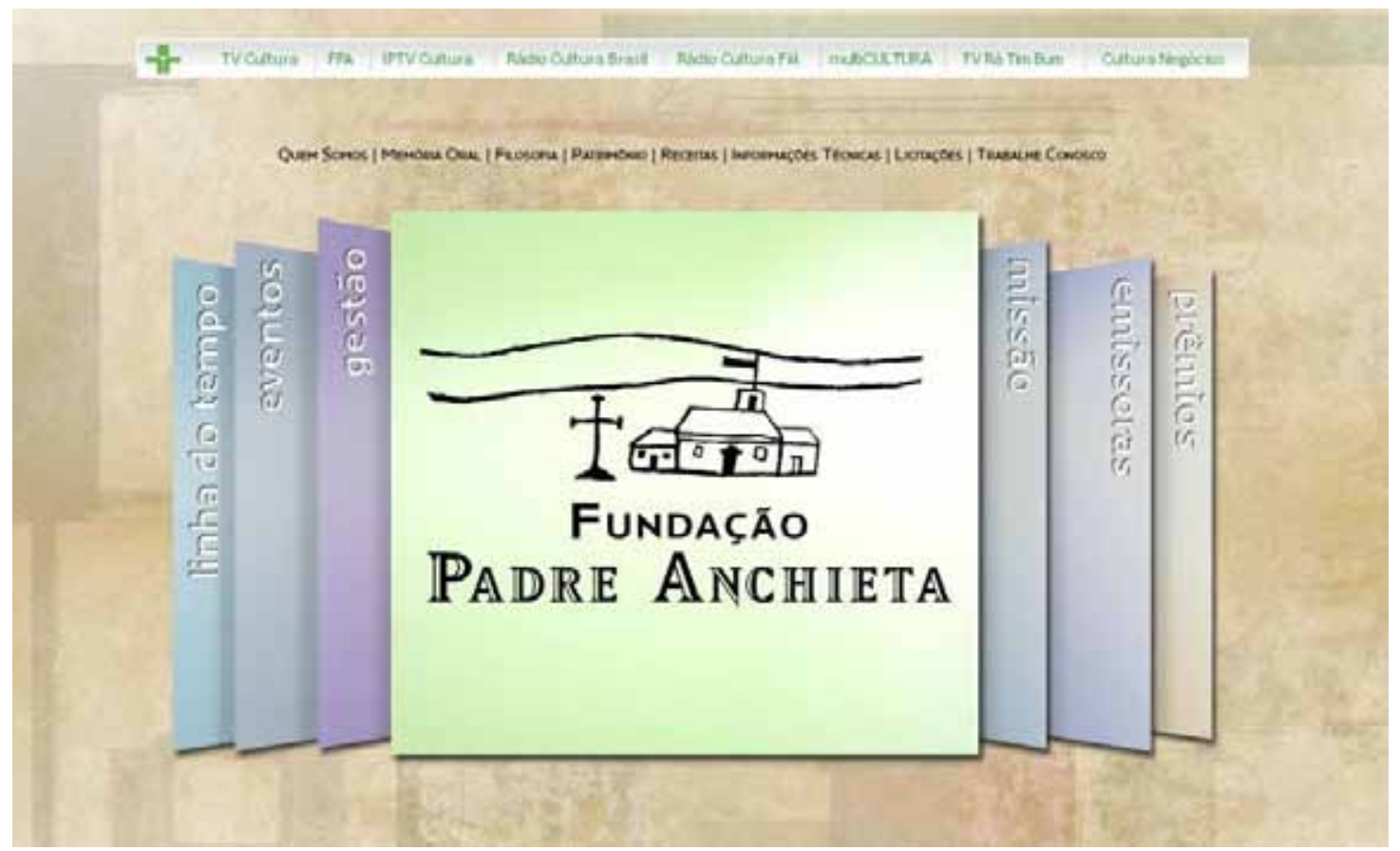

Figura 16 - Logomarca da Fundação Padre Anchieta. Fonte: Fundação Padre Anchieta.

46.Ver: $<$ http://www2.tvcultura.com.br/fpa/>
São Paulo. Pode-se vê-lo, desde 1967, como logomarca da Fundação Padre Anchieta, entidade mantenedora da Rádio e Televisão Cultura. Esse talvez seja o momento de maior absorção, pelo público em geral, dessa herança cartográfica, pois ela se encontra em ambiente virtual e aberto, acessível a quem esteja conectado à rede mundial de computadores (Figura 16$)^{46}$.

\section{Conclusões}

A proposta de percepção de ideias existente na obra organizada por Taunay, publicada em 1922 - em especial a estampa reproduzida do mapa de 1628 -, não se esgota na apresentação do Mappa de Xeria: propaga-se de forma crescente, agregando novos valores e significados. Torna-se interessante observar que, consagrada, tal obra atinge seu objetivo, devido à necessidade de um grupo político hegemônico, no caso o paulista, de legitimar seus interesses políticos, agregando, a esse fato, uma origem histórica "de destaque".

Pela percepção e análise da reprodução do mapa de Céspedes Xeria, tal realidade se consagra como uma história em que verdade absoluta de um momento se deposita em documentação que, na época de sua publicação inicial, não passou por análise criteriosa de seu conteúdo ou procedência.

Nota-se, também, que há dois momentos distintos de divulgação da obra de Taunay. $\bigcirc$ primeiro associa-se à sua aparição inicial, em 1922, e à 
afirmação do Mappa como documentação primária da história paulista, tendo esse conteúdo imagético se diluído em obras didáticas produzidas dessa data até, aproximadamente, 1980.

O segundo momento ocorre a partir de 2000, ano das comemorações dos 500 anos de "descobrimento" do Brasil, quando o mapa de Céspedes Xeria passa a ser quase obrigatório ao tratar-se de assunto referente ao imaginário de São Paulo (cidade e território), no período inicial de colonização.

A ausência de um documental rico e pormenorizado do território paulista (e mesmo da vila de São Paulo) na época inicial de sua colonização sempre foi um problema crítico para criar-se um imaginário ilustrativo do período.

Nesse aspecto, é compreensível que a produção editorial, após as comemorações dos 500 anos do "descobrimento" do Brasil, prenda-se a publicar, de forma constante, a reprodução do mapa de 1628, pois ela se torna a única fonte de iconografia a ilustrar o início do processo de ocupação do território paulista. Existe, nesse processo e em sua constante propagação, a preocupação em estabelecer uma espécie de "certidão de nascimento" para a cidade de São Paulo.

mapa original de Céspedes Xeria é, de fato, um documento importante para o conhecimento dos inícios da colonização do território paulista. Sua divulgação, de forma correta, vai garantir a continuidade de pesquisas voltadas para a necessidade primeira de sua produção nessa época, além de garantir a análise crítica correta do imaginário cultural existente quando de seu aparecimento.

\section{REFERÊNCIAS}

\section{CARTOGRAFIA}

[DIAZ, Santiago Monteiro]. Mappa de D. Luis de Céspedes Xeria. 1917. 1 mapa, 1,89 m x 0,79 m, [reprodução de] original aquarelado e colorido pertencente Archivo General de Indias, Sevilha, Espanha.Acervo de Obras Raras, Biblioteca da Faculdade de Filosofia, Letras e Ciências Humanas da Universidade de São Paulo, São Paulo. OBRA ESP T2262c XERIA, D. Luis de Céspedes. Mapa del Río Ayembí, que recorrió el Gobernador del Paraguay, D. Luis de Céspedes Jeria al entrar en su Gobernación por la via del Brasil.1628. 1 mapa, 1,89 m x 0,79 m, colorido. Sevilha:Archivo General de Indias. ES.41091. AGI/16418.3//MP-BUENOS_AIRES,17BIS

\section{LIVROS, ARTIGOS E SÍTIOS}

ALBUQUERQUE, Manoel M.; CARVALHO, Delgado de.; REIS, Arthur C. F; (Orgs.). Atlas histórico escolar: $7^{\mathrm{a}}$ ed. Rio de Janeiro: Fename/MEC, 1977.

BASTOS, Sênia. Responsabilidade social,turismo e patrimônio histórico cultural paulistano:azulejos, aquarelas e pinturas históricas de José Wasth Rodrigues. In:SEMINÁRIO DE PESQUISA EMTURISMO DO MERCOSUL, 4.,2006, Caxias do Sul-RS.Anais eletrônicos. . Caxias do Sul,UCS, 2006. Disponível em:<http://www. ucs.br/ucs/tplSemMenus/posgraduacao/strictosensu/turismo/seminarios/seminario_4/arquivos_4_seminario/GT04-14.pdf>.Acesso em: 23 abr. 2010. 
BARRETO, Benedito Carneiro Bastos (Belmonte). No tempo dos bandeirantes. São Paulo: Governo do Estado de São Paulo, 1980.

BREFE, Ana Claudia Fonseca. O Museu Paulista: Affonso de Taunay e a memória nacional. São Paulo: Editora da Unesp, 2005.

BUENO, Eduardo (Org.). Os nascimentos de São Paulo. Rio de Janeiro: Ediouro, 2004.

BLAJ, Ilana. Agricultores e comerciantes em São Paulo nos inícios do século XVIII: o processo de sedimentação da elite paulistana. Revista Brasileira de História, São Paulo, v. 18, n. 36, p. 281-296, 1998. Disponível em: <http://www.scielo.br/scielo.php?pid=S0102$-01881998000200012 \&$ script $=$ sci_arttext $\#$ 8not $>$.Acesso em: 23 abr. 2010.

CAVENAGHI, Airton J. São José do Rio Preto fotografado: imagética de uma experiência urbana (1852-1910). Revista Brasileira de História, São Paulo, v. 23, n. 46, p. 147-169, 2003.

O território paulista na iconografia oitocentista: mapas, desenhos e fotografias. Análise de uma herança cotidiana. Anais do Museu Paulista, São Paulo, v. 14, n. 1, p. 195-241, jan.-jun. 2006.

CLETO, Marcelino P. et al. Roteiros e notícias de São Paulo Colonial. São Paulo: Governo do Estado de São Paulo, 1978. (Paulística, 1).

DICK, Maria Vicentina de Paula do Amaral. A dinâmica dos nomes da cidade de São Paulo (1554-1897). São Paulo:Annablume, 1997.

DUARTE, Raul. São Paulo de ontem e de boje. São Paulo: Gráfica da Revista dos Tribunais, 1941.

DURHAM, Eunice Ribeiro. Uma nova visão da antropologia. In: wski. São Paulo: Ática, 1986. (Org.) Bronislaw Malino-

FERNANDES, Florestan. A etnologia e a sociologia no Brasil. São Paulo:Anhambi, 1958.

FERREIRA, Mario Clemente. Cartografar o sertão: a representação de Mato Grosso no século XVIII. In: SIMPÓSIO LUSO-BRASILEIRO DE CARTOGRAFIA HISTÓRICA, 2., 25-26 out. 2007, Lisboa. Anais eletrônicos... Lisboa: Igeo, 2007. Disponível em: <http://www.igeo.pt/servicos/CDI/ PDF/022_MarioClementeFerreira.pdf>.Acesso 23 jul. 2010.

FUNDAÇÃO PADRE ANCHIETA. [Portal do site da Instituição]. Disponível em: <http://www2. tvcultura.com.br/fpa>.Acesso 26 ago 2010.

FUNDAÇÃO ROBERTO MARINHO. Telecurso 2000. 2. Grau; História do Brasil, 1. Fascículo. Rio de Janeiro: Fundação Roberto Marinho, 1995.

HARLEY, John Brian. La nueva naturaleza de los mapas: ensayos sobre la historia de la cartografia. México: Fondo de Cultura Econômica, 2005.

HOLANDA, Sérgio Buarque de. Caminhos e fronteiras. 3. ed. São Paulo: Companhia das Letras, 1994.

KEATING, Vallandro; MARANHÃO, Ricardo. Caminbos da conquista: a formação do espaço brasileiro. São Paulo:Terceiro Nome, 2008.

KOSSOY, Boris. Fotografia e bistória. 2. ed. São Paulo:Ateliê Editorial, 2001. 
KOK, Gloria.Vestígios indígenas na cartografia do sertão da América Portuguesa.Anais do Museu Paulista, São Paulo, v. 17, n. 2, p. 91-109, jul.-dez. 2009.

LIMA, Solange Ferraz de; CARVALHO, Vânia Carneiro de. São Paulo Antigo, uma encomenda da modernidade: as fotografias de Militão nas pinturas do Museu Paulista. Anais do Museu Paulista, São Paulo, v. 1, n.1, p. 147-178, 1993.

. Fotografia e cidade: da razão urbana à lógica de consumo. Álbuns de São Paulo (18871954). Campinas: Mercado das Letras; São Paulo: Fapesp, 1997.

MALINOWSKI, Bronislaw. Uma teoria científica da cultura. Rio de Janeiro: Zahar, 1975.

MARINS, Paulo C. G. Vida cotidiana entre os paulistas: moradias, alimentação, indumentária. In: SETUBAL, Maria Alice (Org.). Terra paulista: histórias, arte, costumes, 2. São Paulo: Cenpec; Imesp, 2004. p. 89-190.

OLIVEIRA, Cecília Helena de Salles Oliveira; MATTOS, Claudia Valladão de (Org.). O brado do Ipiranga. São Paulo: Edusp, 1999.

PASTELLS, R. P. Pablo. Historia de la Compañía de Jesús en la Provincia del Paraguay (Argentina, Paraguay, Uruguay, Perú, Bolivia y Brasil). I. Según los documentos originales Archivo General de Indias. Madrid: Librería General de Victoriano Suárez, 1912.

RODRIGUES, José Wasth. São Paulo Antigo. Documentário n. 1. 25 aquarelas enumeradas. São Paulo: s.e., [195?].

Documentário arquitetônico: relativo à antiga construção civil no Brasil. 4. ed. São Paulo: Edusp; Belo Horizonte: Itatiaia, 1979.

SILVA, James Roberto da. Doença, fotografia e representação: revistas médicas em São Paulo e Paris (1868-1925). São Paulo: Edusp, 2009.

SILVA, Janice Theodoro da. São Paulo (1554-1880): discurso ideológico e organização espacial. São Paulo: Moderna, 1984.

SIMÕES JUNIOR, José Geraldo. Urbanismo: Centro da Cidade. In: Militão de Azevedo e a cidade de São Paulo. CD-ROM. São Paulo :ATR Multimedia e Museu Paulista-USP, 1997.

SOUZA, Jonas Soares de; MAKINO, Miyoko (Org.). Diário da navegação. São Paulo: Edusp; Imprensa Oficial, 2000.

RÜSEN, Jörn. Razão Histórica. Teoria da história: os fundamentos da ciência histórica. Brasília: Editora UnB, 2001.

Artigo apresentado em 9/2010. Aprovado em 4/201 1. 